\begin{tabular}{|c|c|}
\hline & $\begin{array}{l}\text { International Journal of Trend in Scientific } \\
\text { Research and Development (IJTSRD) }\end{array}$ \\
\hline $\begin{array}{lll} & \\
0\end{array}$ & International Open Access Journal \\
\hline 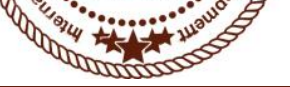 & ISSN No: $2456-6470 \mid$ www.ijtsrd.com | Volume - 2 | Issue -5 \\
\hline
\end{tabular}

\title{
Effect of Steel Fibre Reinforcement on Early Strength of Concrete
}

\author{
Kamran Mohi Ud Din Bhat ${ }^{1}$, Mohd Zeeshan Khan ${ }^{2}$ \\ ${ }^{1}$ Student, ${ }^{2}$ Assistant Professor \\ Alfalah University, Faridabad, Haryana, India
}

\section{ABSTRACT}

Cement concrete is the most extensively used construction material in the world. The reason for its extensive use is that it provides good workability and can be moulded to any shape. Ordinary cement concrete possesses a very low tensile strength, limited ductility and little resistance to cracking, internal micro cracks, leading to brittle failure of concrete. In this modern age, civil engineering constructions have their own structural and durability requirements, every structure has its own intended purpose and hence to meet this purpose, modification in traditional cement concrete has become mandatory. It has been found that different type of fibers added in specific percentage to concrete improves the mechanical properties, durability and serviceability of the structure. It is now established that one of the important properties of Steel Fiber Reinforced Concrete (SFRC) is its superior resistance to cracking and crack propagation. In this study the effect of Steel fibers on early strength of concrete have been studied by varying the percentage of fibers in concrete. The Chemical admixture used in the concrete is $\mathrm{CaCl} 2$ (Accelerator).Fibre content were varied by $0 \%$, $0.50 \%, 0.75 \%, 1 \%, 1.5 \%$ and $2 \%$ by volume of concrete. Cubes of size $150 \mathrm{mmX} 150 \mathrm{mmX} 150 \mathrm{~mm}$ to check the compressive strength, Cylinders of size $100 \mathrm{~mm} \times 200 \mathrm{~m}$ to check the split tensile strength and beams of size $500 \mathrm{mmX} 100 \mathrm{mmX} 100 \mathrm{~mm}$ for checking flexural strength were casted. All the specimens were cured for the period of 3,7 and 28 days before crushing. The results of Steel fiber reinforced concrete on early strength for 3days, 7days and 28days curing with varied percentage of fiber were studied and it has been found that there is significant strength improvement in Early Strength concrete. The optimum fiber content while studying the compressive strength, Split tensile strength and flexural strength is found to be $1.25 \%$. Also, it has been observed that with the increase in fiber content up to the optimum value, the concrete gains maximum compressive strength at 28 days curing while split tensile and flexural performance shows maximum percentage increase in strength in first 3 days of curing. Slump cone test was adopted to measure the workability of concrete. The Slump cone test results revealed that workability gets reduced with the increase in fiber content.

Keywords: FIBRE REINFORCEMENT, STEEL, COMPRESSIVE STRENGTH, FLEXURAl STRENGTH

\section{INTRODUCTION}

\subsection{BACKGROUND}

The project entitled "Effect of fibre reinforcement on high early strength concrete " is an investigation based project wherein we have tried to investigate the properties of high performance concrete, which in this case is high early strength concrete upon fibre reinforcement. This project is a vast subject for research and would require a hefty amount of time and material for an extensive database research, however we have limited our study to only a few conditions and properties so as to complete our objectives within stipulated time

The main objectives of this study are summarized .as:

1. To establish a comprehensive and consistent database on HESFRCregarding its use in common engineering situations

2. To document and synthesize information on properties of HESFRC

3. To develop new, significantly improved 
engineering criteria for behavior and mechanical properties of HESFRC

4. To develop some guidelines and practical recommendations for professional use of HESFRC according to intended use and suitability.

Although a number of investigations have been dealt with Fibre Reinforced and High performance concrete before however we don't have much literature on fibre reinforcement of high early strength concrete. The main intent will be to achieve, besides minimum compressive strength, a post cracking strength in bending higher than the cracking strength so as to minimize crack widths and also ensure a higher resistance to repeated loads after cracking. Particular attention will be given to recording key parameters such as compressive strength, tensile strength, flexural strength and their variation with different percentages of fibre addition.

\section{OBJECTIVES}

The main objectives of this investigation will be

1. To establish a consistent and comprehensive database on the properties of high early strength fibre reinforced concrete (HESFRC)

2. To document and synthesize information on the properties of the fresh mix and the mechanical properties of the hardened composite, and

3. To develop some practical recommendations for use of HESFRC by the profession.

The experimental investigation included several parts dealing with the properties of HESFRC: the properties of the fresh mix (workability by the slump test and unit weight), and the compressive and tensile, properties of the hardened composite. Only HESFRC will be considered which has been already defined as achieving a minimum target compressive strength of $35 \mathrm{MPa}$ in 24 hours

In relation to the part of the experimental program dealing with the compression tests, following goals will be undertaken:

1. To measure the fresh properties of various HESFRC mixes, which include plastic unit weight, workability (using the cone test)

2. To determine the values of strength and modulus of elasticity of the composite and their variation with time between 1 day and 28 days.
As far as current application of FRC is concerned, a low \%age of fibres (0.01-1.0\%) is being used. In this study, we will try higher \%ages of fibres (up to $2 \%$ )

\section{SCOPE}

High early strength concrete, when reinforced with fibres, can be used for several highway related applications. They include repair-type applications for which early strength properties are needed such as for potholes, bridge decks, overlays, pavement joints, and runways; and applications in new structures particularly bridge decks, pavements, median barriers, taxiways, and runways. Tunnel lining, slope stabilisation, dams, hydraulic structures, and blast resistant structures also utilize high early strength fibre reinforced concrete for various purposes. These are applications in which the specific advantages of HESFRC compared with HES concrete without fibres are needed, such as its increased resistance to cracking, its increased toughness (i.e., energy absorption capacity against dynamic and impact loadings), its increased ductility, and its increased fatigue life.

Moreover, HESFRC can be used in reinforced and prestressed concrete structures to replace the plain concrete matrix in these structures. In such cases, its use is expected to lead to substantially improved structural ductility, better hysteretic response under cyclic load reversals, better bonding of the reinforcing bars and prestressing tendons, improved resistance of the concrete cover to spalling, smaller crack widths, and overall improved energy absorption capacity of the structure.

\section{METHODOLOGY}

The procedure involved in our project work is summarized as:

\section{Collection and testing of materials}

The materials were collected from the university construction sites and stored in the laboratory and the necessary tests were carried out.

Fineness test and initial setting time of OPC and OPC with admixture was carried out. Sieve analysis of fine aggregates was done. For coarse aggregates, flakiness index, elongation index, abrasion, AIV, aggregate crushing value was done. The steel fibres needed to be cut to required size. The chemical was also powdered before use. 


\section{Concreting}

Concrete was formed at different percentages of fibres, which varied as $0 \%, 0.5 \%, 0.75 \%, 1.0 \%$, $1.25 \%, 1.5 \%$ and $2.0 \%$ Concreting was done by design mix procedure. Atmospheric conditions were moderate temperature with average humidity.

After concreting, workability tests of all samples were carried out.

\section{Casting of cubes, cylinders and beams}

After concreting was done, concrete was poured into cube, cylinder, and beam moulds. The moulds were compacted after that and left as such for 24 hours.

Curing was done by placing the specimen in curing tank till 6 hours before testing.

\section{Testing of samples}

Samples were tested for various loadings. Cubes were put to compression, beams to two point loading for flexure and cylinders were subjected to split tensile strength. Each test was carried out on 3 samples and the arithmetic average was taken as the mean value.

Quality control was maintained throughout the project. All the steps were carried out as per Indian standards enlisted below:

1. IS 456:2000 concrete design

2. Is 10262:2009 concrete mix proportions

3. Is 4031:1988 part iv Guidelines for method of test of aggregate

4. Is 4031:1988 part v- Guidelines for method of test of aggregate

5. Is $12269: 1988$ grade cement

6. Is $383: 1970$ coarse and fine aggregates

7. Is $4926: 2003$ ready mix concrete
Code of practice for

Guidelines for
Specifications for
Code of practice for

Specifications for 53

\section{STRUCTURE OF PROJECT}

GENERAL STUDIES

Literature

- Fibre reinf orced concrete

- Effects of adding admixtures on concrete
IS CODES

- IS 456:2000

- IS 10262:2009

- $1512269: 1988$
SITE SELECTION FOR COLLECTION OF SAMPLES
PRELIMINARYTESTING OF MATERIALS 


\section{LITERATURE REVIEW}

\section{CONCRETE}

Concrete is the most widely used manmade construction material used on earth and is only second to water as the most utilized substance on the planet. a composite mixture obtained by mixing cement, water and an inert matrix of sand and gravel or crushed stone, and when placed in forms, allowed to cure, hardens into a rock like mass known as cement concrete. The strength, durability and other properties of concrete depend on properties of its ingredients, on proportion mix, the method of compaction and other controls during placing, compaction, and curing.

\section{INGREDIENTS OF CONCRETE}

Concrete consists of two types of ingredients viz Active and Inactive. Active group consists of cement and water whereas inactive group consists of fine and coarse aggregates. The in active group isalso sometimes called as inert matrix. These ingredients are discussed as:

\section{A. Cement}

Although all the materials that go into concrete are essential but by far cement is the most important constituent because it is the most delicate link of the chain. The main function of the cement is to bind sand and coarse aggregates to form a compact mass.

\section{Composition of cement}

Cement comprises of compounds of calcium, silicon, aluminum, iron, and oxygen. The main function of cement is to bind the aggregates and to fill the voids in between the aggregates. The most commonly used cement is the Ordinary Portland Cement (OPC). It is obtained by burning together, in a definite proportion, a mixture of naturally occurring argillaceous and calcareous material to a partial fusion at high temperature $\left(1450^{\circ} \mathrm{C}\right)$.

The composition of OPC is rather complicated but basically it comprises of four main compounds

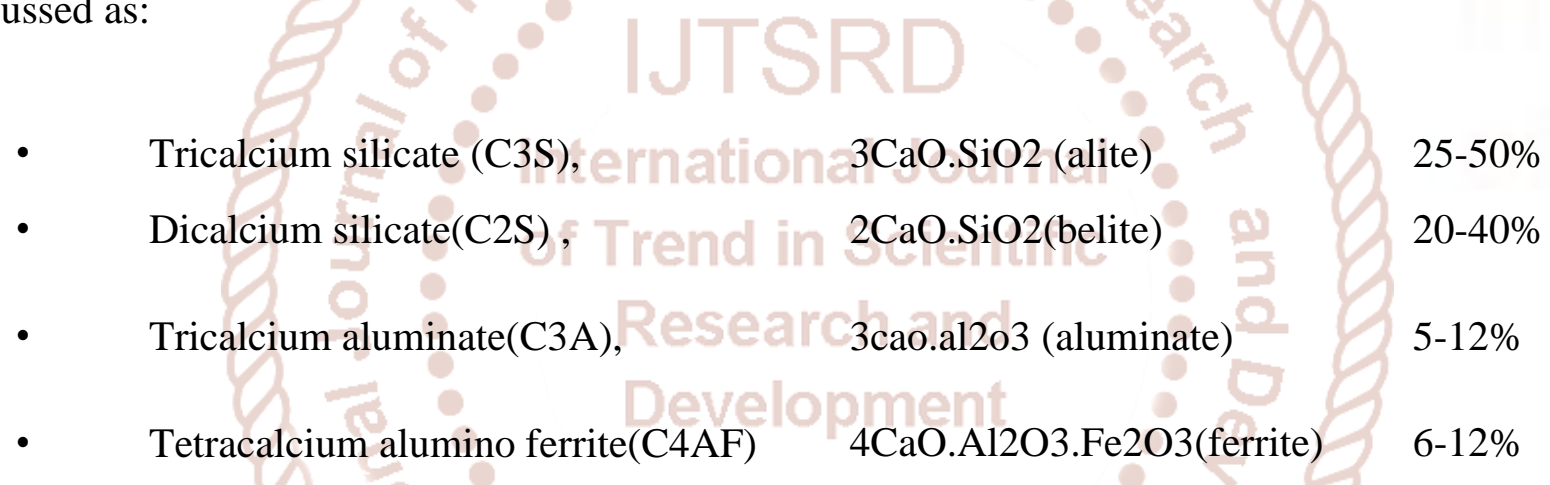

within it, and makes it flow more freely. A lower water-to-cement ratio yields a stronger, more durable concrete, whereas more water gives a freer-flowing concrete with a higher slump. Impure water used to make concrete can cause problems when setting or in causing premature failure of the structure.

Hydration involves many different reactions, often occurring at the same time. As the reactions proceed, the products of the cement hydration process gradually bond together the individual sand and gravel particles and other components of the concrete to form a solid mass.

\section{Admixture}

Chemical admixtures are materials in the form of powder or fluids that are added to the concrete to give it certain characteristics not obtainable with plain concrete mixes. Accelerators speed up the hydration (hardening) of the concrete. Typical materials used are $\mathrm{CaCl} 2, \mathrm{Ca}(\mathrm{NO} 3) 2$ and $\mathrm{NaNO} 3$. Accelerating admixtures are especially useful for modifying the 
properties of concrete in cold weather. While as retarders slow the hydration of concrete and are used in large or difficult pours where partial setting before the pour is complete is undesirable. Typical polyol retarders are sugar, sucrose, sodium gluconate, glucose, citric acid, and tartaric acid.

Plasticizers increase the workability of plastic or "fresh" concrete, allowing it be placed more easily, with less consolidating effort. A typical plasticizer is lingo-sulfonate. Plasticizers can be used to reduce the water content of a concrete while maintaining workability and are sometimes called water-reducers due to this use. Such treatment improves its strength and durability characteristics

\section{HIGH PERFORMANCE CONCRETE (HPC)}

In recent years, improvements in properties of concrete have been achieved in the so called High performance concrete by improvements involving a combination of improved compaction, improved paste characteristics and aggregate-matrix bond and reduced porosity. Subsequent reduction in water cement ratio is achieved through use of plasticisers. Although HPCs are made from same materials as normal concrete but they are considered quite different materials due to their higher qualitative and quantitative performances. They offer different advantages such as enhanced durability, reduced permeability, higher strength, early setting etc. Based on characteristic strength, a concrete can be called as HPC if it produces a strength of 600- $100 \mathrm{Mpa}$ in 28 days (compared to 10-20 of ordinary concrete). Fibre reinforcing concretes are becoming quite a common today due to accessory advantages besides increase in strength and reduction in cost. High early strength is a common HPC used mainly in underground construction, repair works, construction on busy routes etc.

There are three methods which make adjustments to obtain high-early strength in concrete:

1. Adding $30 \%$ more cement by weight to the normal cement content (the fine aggregate is reduced) while the water and air contents remain unchanged.

2. Adding chemical admixtures to the standard mix.

3. A combination of 1 and 2 .

The additional $30 \%$ cement or addition of a water reducer increases the cement-voids ratio of the mix and thereby strength is increased. Accelerating admixtures added to a standard mix, without changing the cement or water content, increase the rate of hydration thereby increasing the early strength but reducing the ultimate strength.

Increasing the cement content $30 \%$ produces highearly strength concrete. Do not increase the water content more than $5 \%$ over that used with the normal cement content. There is a tendency to increase the water content to the extent that the same slump is obtained. The addition of excess water will nullify the benefits of the increased cement content and produce a lower early and lower ultimate strength than anticipated. The actual slump value is less in a higher cement content mix due to the increased workability of the mixture that is a result of the high cement content. The lower slump concrete with the additional cement is just as workable as the normal concrete

\section{FIBRE REINFORCED CONCRETE}

Concrete is the most widely used man-made construction material in the world, and is second only to water as the most utilized substance on the planet. It is obtained by mixing cementing materials, water and aggregates, and sometimes admixtures, in required proportions. The mixture when placed in forms and allowed to cure hardens into a rock-like mass known as concrete. The strength, durability and other characteristics of concrete depend upon the properties of its ingredients, on the proportions of mix, the method of compaction and other controls during placing, compaction, and curing. Concrete is weak in tension and has a brittle character. The concept of using fibres to improve the characteristics of construction materials is very old. Early applications include addition of straw to mud bricks, horse hair to reinforce plaster and asbestos to reinforce pottery. Use of continuous reinforcement in concrete (reinforced concrete) increases strength and ductility, but requires careful placement and labour skill. Alternatively, introduction of fibres in discrete form in plain or reinforced concrete may provide a better solution. The modern development of fibre reinforced concrete (FRC) started in the early sixties. Addition of fibres to concrete makes it a homogeneous and isotropic material. When concrete cracks, the randomly oriented fibres start functioning, arrest crack formation and propagation, and thus improve strength and ductility. The failure modes of FRC are either bond failure between fibre and matrix or material failure. 
Fibres are produced from different materials in various shapes and sizes. Typical fibre materials are:

\section{$>$ Steel Fibres}

Straight, crimped, twisted, hooked, ringed, and paddled ends. Diameter range from

0.25 to $0.76 \mathrm{~mm}$.

\section{Glass Fibres}

Straight. Diameter ranges from 0.005 to $0.015 \mathrm{~mm}$ (may be bonded together to form elements with diameters of 0.13 to $1.3 \mathrm{~mm}$ ).

Natural Organic and Mineral Fibres

Wood, asbestos, cotton, bamboo, and rock-wool. They come in wide range of sizes.

Polypropylene Fibres

Plain, twisted, fibrillated, and with buttoned ends.

$>$ Other Synthetic Fibres

Kevlar, nylon, and polyester. Diameter ranges from 0.02 to $0.38 \mathrm{~mm}$.

A convenient parameter describing a fibre is its aspect ratio (LID), defined as the fibre length divided by an equivalent fibre diameter. Typical aspect ratio ranges fromabout 30 to 150 for length of 6 to $75 \mathrm{~mm}$.

A shortcoming of using fibres in concrete is reduction in workability. Workability of FRC is affected by fibre aspect ratio and volume fraction as well the workability of plain concrete. As fibre content increases, workability decreases. Most researchers limit volume of fibres to $4.0 \%$ and aspect ratio to 100 to avoid unworkable mixes. In addition, some researchers have limited the fibre reinforcement index [volume of fibres as $\%$ xaspect ratio] to 1.5 for the same reason. To overcome the workability problems associated with FRC, modification of concrete mix design is recommended. Such modifications can include the use of additives.

\section{HISTORY}

The use of fibers to increase the structural properties of construction material is not a new process. From ancient times fibers were being used in construction. In BC, horse hair was used to reinforce mortar. Egyptians used straw in mud bricks to provide additional strength. Asbestos was used in the concrete in the early 19th century, to protect it from formation of cracks. But in the late 19th century, due to increased structural importance, introduction of steel reinforcement in concrete was made, by which the concept of fiber reinforced concrete was over looked for 5-6 decades. Later in 1939 the introduction steel replacing asbestos was made for the first time. But at that period it was not successful. From 1960, there was a tremendous development in the FRC, mainly by the introduction of steel fibers. Since then use of different types of fibers in concrete was made. In 1970's principles were developed on the working of the fibres reinforced concrete. Later in 1980's certified process was developed for the use of FRC. In the last decades, codes regarding the FRC are being developed.

\section{PROPERTIES OF FIBRE REINFORCED CONCRETE}

Properties of concrete is affected by many factors like properties of cement, fine aggregate, coarse aggregate. Other than this, the fibre reinforced concrete is affected by following factors:

$>$ Type of fibre

$>$ Aspect ratio

$>$ Quantity of fibre

Orientation of fibre

Type of fibre:

A good fibre is the one which possess the following qualities:

Good adhesion within the matrix.

Adaptable elasticity modulus (sometimes higher than that

of the matrix)

$>$ Compatibility with the binder, which should not be attacked or destroyed in the long term

An accessible price, taking into account the proportion within the mix being sufficiently short, fine and flexible to permit mixing, transporting and placing

Being sufficiently strong, yet adequately robust to withstand the mixing process.

\section{Aspect ratio:}

Aspect ratio is defined as the ratio of length to width of the fibre. The value of aspect ratio varies from 30 to 150 . Generally the increase in aspect ratio increases the strength and toughness till the aspect ratio of 100 . Above that the strength of concrete decreases, in view of decreased workability and reduced compaction. From investigations it can be found out that good results are obtained at an aspect ratio around 80 for steel fibres. Keeping that in view we have considered 
steel crimped fibres with aspect ratio of 50-80 (Length 40-50 $\mathrm{mm}$ and Diameter $0.75 \mathrm{~mm}$ ).

\section{Fibre quantity:}

Generally quantity of fibres is measured as percentage of cement content or concrete. As the volume of fibres increase, there should be increase in strength and toughness of concrete. Regarding our fibre, we hope that there will be an increase in strength, with increase in fibre content. We are going to test for percentages of $0,0.5,0.75,1.0,1.25,1.5$, and $2.0 \%$ volume of concrete

\section{Orientation of fibre:}

The orientations of fibres play a key role in determining the capacity of concrete. In RCC the reinforcements are placed in desired direction. But in FRC, the fibres will be oriented in random direction. The FRC will have maximum resistance when fibres are oriented parallel to the load applied.

The stress strain curve of concrete under uniaxial compression shows a linear behaviour up to about $30 \%$ of the ultimate strength (fu) because under short term loading the micro cracks in the transition zone remain undisturbed. For stresses above this point, the curve shows a gradual increase in curvature up to about 0.75 fu to 0.9 fu, then it bends sharply almost becoming flat at the top and finally descends until the specimen is fractured.

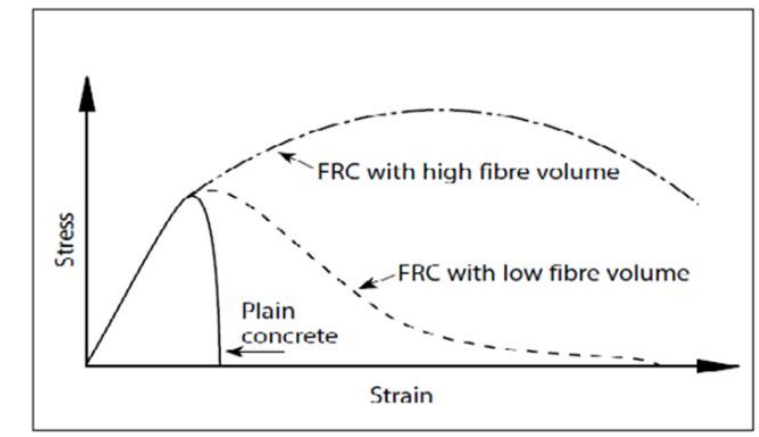

\section{FIG 1: STRESS-STRAIN CURVE OF ORDINARY AND FIBRE REINFORCED CONCRETE}

\section{STEEL FIBRES}

Steel fibres have been used in concrete since the early 1900s. The early fibres were round and smooth and the wire will be cut or chopped to the required lengths. The use of straight, smooth fibres has largely disappeared and modern fibres have either rough surfaces, hooked ends or are crimped or undulated through their length. Modern commercially available steel fibres are manufactured from drawn steel wire, from slit sheet steel or by the melt-extraction process which produces fibres that have a crescent-shaped cross section Typically steel fibres have equivalent diameters (based on cross sectional area) of from 0.15 $\mathrm{mm}$ to $2 \mathrm{~mm}$ and lengths from 7 to $75 \mathrm{~mm}$. Aspect ratios generally range from 20 to 100 . (Aspect ratio is defined as the ratio between fibre length and its equivalent diameter, which is the diameter of a circle with an area equal to the cross-sectional area of the fibre). Carbon steels are most commonly used to produce fibres but fibres made from corrosionresistant alloys are available. Stainless steel fibres have been used for high-temperature applications.

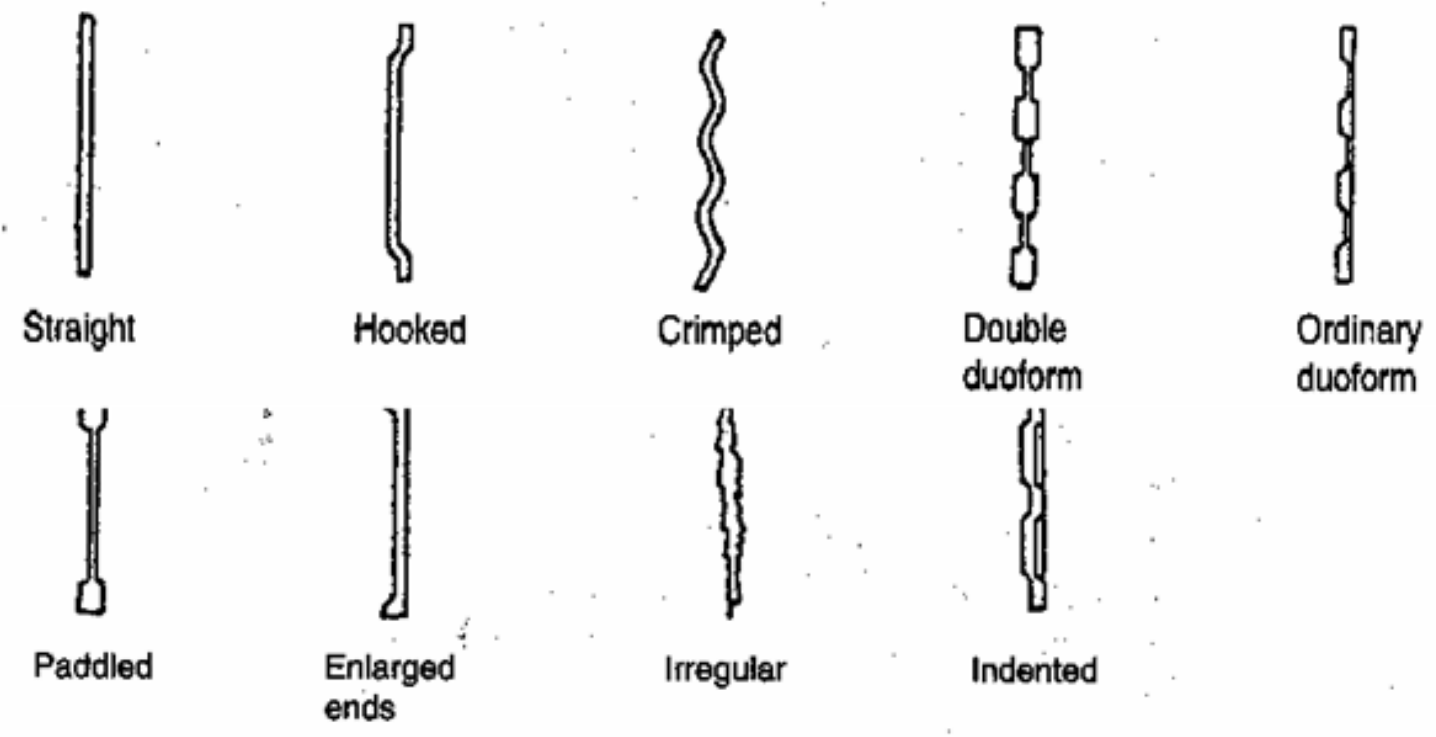

HG 2: DIFFERENT S HAPES OF STEEL RBRES 
Steel fibres have been used in conventional concrete mixes, shotcrete and slurry- infiltrated fibre concrete. Typically, content of steel fibre ranges from $0.25 \%$ to $2.0 \%$ by volume. Fibre contents in excess of $2 \%$ by volume generally result in poor workability and fibre distribution, but can be used successfully where the paste content of the mix is increased and the size of coarse aggregate is not larger than about $10 \mathrm{~mm}$. Some fibres are collated into bundles using watersoluble glue to facilitate handling and mixing. Steel fibres have high tensile strength $(0.5-2 \mathrm{GPa})$ and modulusof elasticity (200 GPa), a ductile/plastic stress-strain characteristic and low creep. Steel-fibrereinforced concrete containing up to $1.5 \%$ fibre by volume has been pumped successfully using pipelines of 125 to $150 \mathrm{~mm}$ diameter. Steel fibre contents up to $2 \%$ by volume have been used in shotcrete applications using both the wet and dry processes. Steel fibre contents of up to $25 \%$ by volume have been obtained in slurry- infiltrated fibre concrete. Concretes containing steel fibre have been shown to have substantially improved resistance to impact and greater ductility of failure in compression, flexure, and torsion. Similarly, it is reported that the elastic modulus in compression and modulus of rigidity in torsion are no different before cracking when compared with plain concrete tested under similar conditions. It has been reported that steel-fibrereinforced concrete, because of the improved ductility, could find applications where impact resistance is important. Fatigue resistance of the concrete is reported to be increased by up to $70 \%$.It is thought that the inclusion of steel fibre as supplementary reinforcement in concrete could assist in the reduction of spalling due to thermal shock and thermal gradients. The lack of corrosion resistance of normal steel fibres could be a disadvantage in exposed concrete situations where spalling and surface staining are likely to occur.

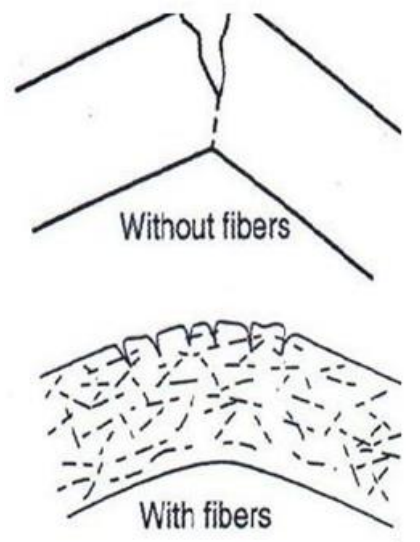

\section{PREVIOUS WORK}

The influence of fibres in improving the compressive strength of the matrix depends on whether mortar or concrete (having coarse aggregates) is used and on the magnitude of compressive strength. Studies prior to 1988 including those of Williamson [1974], Naaman et al. [1974] showed that with the addition of fibres there is an almost negligible increase in strength for mortar mixes; however for concrete mixes, strength increases by as much as $23 \%$.

Furthermore, Otter and Naaman [1988] showed that use of steel fibres in lower strength concretes increases their compressive strength significantly compared to plain un reinforced matrices and is directly related to volume fraction of steel fibre used. This increase is more for hooked fibres in comparison with/straight steel fibres, glass or polypropylene fibres.

Ezeldin and Balaguru [1992] conducted tests to obtain the complete stress strain curves of steel fibrereinforced concrete with compressive strengths ranging from $35 \mathrm{MPa}$ to $84 \mathrm{MPa}(5,000$ to 12,000 psi). The matrix consisted of concrete rather than mortar. Three volume fibres fractions of $50 \mathrm{psi}, 75 \mathrm{psi}$ and $100 \mathrm{psi}(30 \mathrm{~kg} / \mathrm{m} 3,45 \mathrm{~kg} / \mathrm{m} 3$ and $60 \mathrm{~kg} / \mathrm{m} 3)$ and three aspect ratios of 60,75 and 100 were investigated. It was reported that the addition of hooked-end steel fibres to concrete, with or without silica fume, increased marginally the compressive strength and the strain corresponding to peak stress.

Shah and Rangan [1971] proposed the following general equation for predicting the ultimate flexural strength of the fibre composite:

$f c c=A f m(1-V f) B(V f L / d f)$

Where fcc, is the ultimate strength of the fibre composite, $\mathrm{G}$ is the maximum strength of the plain matrix (mortar or concrete), A and B are constants which can be determined experimentally. For plain concrete, $\mathrm{A}=1$ and $\mathrm{B}=0$. The constant $\mathrm{B}$ accounts for the bond strength of the fibres and randomness of fibre distribution. Swamy et al. [1974a] established values for the constants A and B as 0.97 and 4.94 for the ultimate flexural strength of steel fibre-reinforced concrete and 0.843 and 4.25 for its first cracking strength.

FIG 3: ACTION OF STEEL FIBRES 
A comparative evaluation of the static flexural strength for concretes with and without different types of fibres: hooked-end steel, straight steel, corrugated steel, an polypropylene fibres was conducted by Ramakrishnan et al.[1989]. The fibres were tested at $0.5,1.0,1.5$ and $2.0 \%$ by volume. It was reported that maximum quantity of hooked-end fibres that could be added without causing balling was limited to 1.0 percent by volume. Compared to plain concrete, the addition of fibres increased the first cracking strength (15 to 90 percent) and static flexural strength (15 to 129 percent). Compared on equal basis of 1.0 percent by volume, the hooked-end steel fibre contributed to the highest increase, and the straight fibres provided the least appreciable increase in the above mentioned properties.

Ezeidin and Lowe [1991] studied the flexural strength properties of rapid-set materials reinforced with steel fibres. The primary variables were (a) rapid-set cementing materials, (b) Fibre type, and (c) fibre content. Four fibre types made of low-carbon steel were Incorporated in this study. Two were hooked and one was crimped at the ends, and one was crimped throughout the length. Steel fibres were added in the quantities of 50, 75 and $100 \mathrm{lbs} / \mathrm{yd} 3$ (30, 45 and $6 \mathrm{~kg} / \mathrm{m}$ ). An increase in the flexural strength was observed. The fibre efficiency in enhancing the flexural strength is controlled by the fibre surface Deformation, aspect ratio, and fibre content. The results further indicate that steel fibres are very effective in improving the flexural toughness of rapidset materials. Toughness indexes as high as 4 for I5 and 9 for I10 can be achieved with fibre contents of 75 lbs/yd3 (45 kg/m3). Johnston and Zemp [1991] investigated the flexural performance under static loads for nine mixtures, using sets of 15 specimens for each mixture. Each set of 102 x 102 x 356 mm (4 x 4 $\mathrm{x} 14$ in.) specimens were prepared from five nominally identical batches and tested under third point loading over a $305 \mathrm{~mm} 12$ in.) Span. First crack strengths defined in ASTM C. 108 as the point on the load-deflection curve at which the form of the curve first becomes nonlinear, and ultimate strength based on the maximum flexural load (ASTM C 78) were established for the eight fibrous concretes, with only ultimate strength for the plain concrete control.

\section{MATERIALS USED}

\section{Cement}

Ordinary Portland cement is used in the project work, as it is readily available in local market. We used 53 grade cement Khyber cement for our project purpose. The reason for using high grade is that for high performance cements, higher strength is preferable

\section{Coarse Aggregate}

Crushed angular granite metal from a local source was used as coarse aggregate. The specific gravity was 2.71, Flakiness index of $4.58 \%$ and elongation index of $3.96 \%$. The coarse aggregate used in the project work are $20 \mathrm{~mm}$ down grade. The reason for selecting a relatively small-size aggregate is to improve the efficiency of fiber reinforcement.

\section{Fine Aggregate}

River white sand was used as fine aggregate. The specific gravity was 2.55 . The fine aggregate used in the project work is $4.75 \mathrm{~mm}$ down grade.

\section{Fibre}

Stainless steel zinc coated woven crimped wire mesh with dia $0.7 \mathrm{~mm}$ and density 2.9

$-3.0 \mathrm{~kg} / \mathrm{cm} 2$ was used to obtain fibres. The length of fires was kept in the range $3-5 \mathrm{~cm}$. The stainless steel wire mesh was obtained from local market.

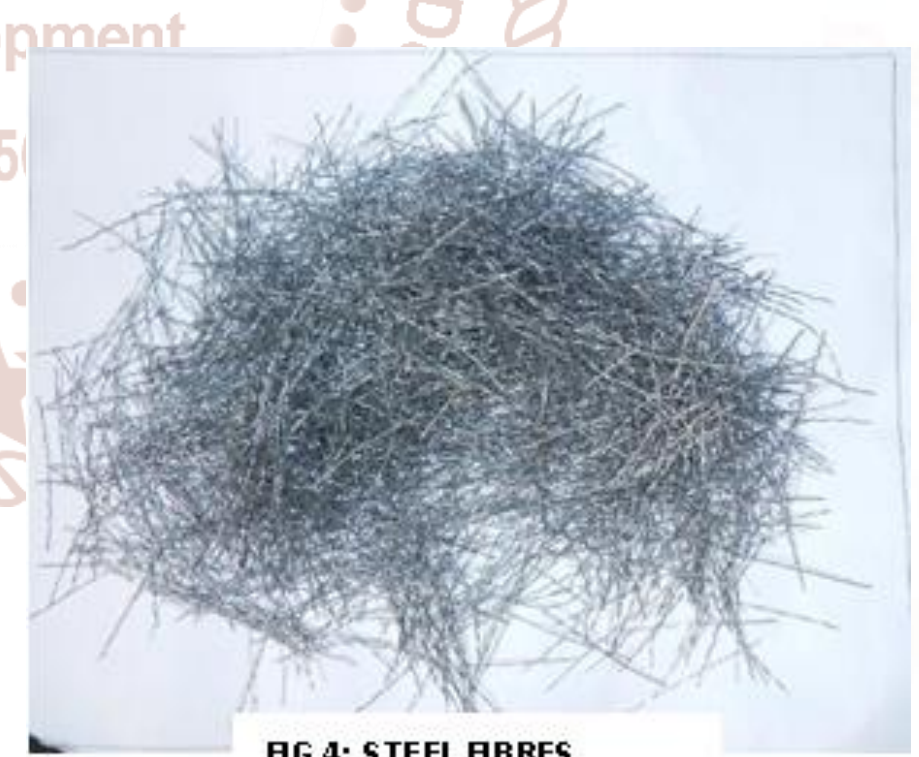

HG 4: STEEL HBRES 
International Journal of Trend in Scientific Research and Development (IJTSRD) ISSN: 2456-6470

TABLE 1: CHEMICAL COMPOSITION OF STEEL FIBRES

\begin{tabular}{|c|c|}
\hline Chemical Composition (Max) & $\begin{array}{c}\text { Ferritic } \\
\text { Stainless } \\
\text { steel }\end{array}$ \\
\hline Carbon & 0.12 \\
\hline Manganese & 1.00 \\
\hline Phosphorus & 0.04 \\
\hline Sulfur & 0.03 \\
\hline Silicon & \\
\hline Chromium & \\
\hline Nickel & \\
\hline Tensile Strength MPa & 517 \\
\hline Yield Strength ( $0.2 \%$ offset) $\mathrm{MPa}$ & 345 \\
\hline $\begin{array}{l}\text { Modulus of Elasticity in Tension } \\
\mathrm{GPa}\end{array}$ & 200 \\
\hline $\begin{array}{l}\text { Modulus of Elasticity in Torsion } \\
\mathrm{GPa}\end{array}$ & 89 \\
\hline Density kg / cubic meter & 7780 \\
\hline
\end{tabular}

\section{Admixture}

Dehydrated calcium chloride, in the form of chunks was used as an accelerator.

\section{Water}

Water to be used in the concrete work should have following properties.

1. It should be free from injurious amount of soils.

2. It should be free from injurious amount of acids, alkalis or other organic or inorganic impurities.

3. It should be free from iron, vegetable matter or any other type of substances which are likely to have adverse effect on concrete or reinforcement.

4. It should be fit for drinking purposes.

The function of water in concrete

$>$ It acts as lubricant

$>$ It acts as chemically with cement to form the binding paste for coarse aggregate and reinforcement.

$>$ It enables the concrete mix to flow into formwork.

\section{EXPERIMENTAL PROGRAM CONCRETE MIX DESIGN MIX DESIGN}

Mix design is the process of selection of suitable ingredients of concrete and to determine their properties with object of producing concrete of certain maximum strength and durability, as economical as possible. The purpose of designing is to achieve the stipulated minimum strength, durability and to make the concrete in the most economical manner.

\section{A. Design Stipulations:}

1, Grade Designation

M25

2, Type of Cement

3, Maximum Nominal size of OPC 53 grade aggregates

4, Minimum cement content $\quad 300 \mathrm{~kg} / \mathrm{m}^{3}$

5 , Maximum water cement ratio 0.50

6, Workability

7, Exposure Condition

50mm (slump)

Moderate

8 , Method of concrete placing

9, Degree of supervision

Hand Placing

Good

10 , Type of aggregate

Crushed angular aggregates

11, Maximum cement content

12, Chemical admixture type

$450 \mathrm{~kg} / \mathrm{m}^{3}$

$\mathrm{Cacl} 2$

\section{B. Test data for materials}

1 , Cement used

2 , Specific gravity of cement

OPC 53 grade

3 , Chemical admixture

3.15

Accelerator

4, Specific gravity of coarse aggregate 2.7

5 , Specific gravity of fine aggregate 2.6

\section{Target strength for mix proportioning}

Target Mean strength, $\mathrm{fck}$ ' $=\mathrm{fck}+\mathrm{ks}$

fck

s

K

Therefore, $\mathrm{fck}^{\prime}=(25+1.65 \times 4)$

$$
=31.6 \mathrm{~N} / \mathrm{mm}^{2}
$$

\section{Selection of water cement ratio}

From table 5 of IS 456-2000, maximum $\mathrm{W} / \mathrm{C}$ ratio $=$ 0.50 , based on experience adopt $\mathrm{W} / \mathrm{C}$ ratio $=0.48$

\section{E. Selection of water content}

From Table 2 (IS-10262-2009), maximum water content for $20 \mathrm{~mm}$ aggregates

$$
=186 \mathrm{~L} \text { (for } 25 \mathrm{~mm} \text { to } 50 \mathrm{~mm} \text { slump) }
$$


International Journal of Trend in Scientific Research and Development (IJTSRD) ISSN: 2456-6470

Therefore estimated water content for $75 \mathrm{~mm}$ slump

$$
\begin{aligned}
& =186+(9 / 100) \times 186 \\
& =203 \mathrm{~L} / \mathrm{m}^{3}
\end{aligned}
$$

\section{F. Calculation of cement content}

$\mathrm{W} / \mathrm{C}$ Ratio $=0.48$

Cement Content $=203 / 0.48=423 \mathrm{~kg} / \mathrm{m}^{3}$

From Table 5 of IS 456-2000, minimum cement content for moderate exposure condition $=300 \mathrm{~kg} / \mathrm{m}^{3}$
$423 \mathrm{~kg} / \mathrm{m}^{3}>300 \mathrm{~kg} / \mathrm{m}^{3}$
Hence
O.K

\section{$=(2 / 100) \mathrm{X} 423$ \\ $=8.46 \mathrm{Kg} / \mathrm{m}^{3}$}

G. Admixture @ 2\%byweight of cement

\section{H. Proportion of volume of coarse aggregate and} fine aggregate content

From Table 3 of IS 10262-2009, for 20mm aggregates and Zone 1 fine aggregates.

Vol. of Coarse aggregates $=60 \%$

Vol. of fine aggregates $\quad=40 \%$

\section{Mix calculations (Mix calculations per unit} volume of concrete)

1. Vol. of Concrete $=1 \mathrm{~m}^{3}$

2. Vol. of Cement

$=($ Mass of cement/Sp. Gravity $) \times(1 / 1000)$

$=(423 / 3.15) \times(1 / 100)$

$0.134 \mathrm{~m}^{3}$

3. Vol. of water

$=($ Mass of water $/ \mathrm{Sp}$. Gravity of water $) \mathrm{x}(1 / 1000)$

$=(203 / 1.0) \times(1 / 100)$

Volume of all in aggregate $=[\mathrm{a}-(\mathrm{b}+\mathrm{c}+\mathrm{d})]$

$=[1-(0.134+0.203+0.00738)]$

$=0.655 \mathrm{~m}^{3}$

4. Mass of Coarse aggregate $=\mathrm{e} x$ vol. of C.A X Sp.

Gravity of F.A X 1000

$=1062 \mathrm{Kg}$.

5. Mass of Fine aggregate $=\mathrm{e} x$ vol. of F.A X

Sp.Gravity of F.A X 1000

$=707.4 \mathrm{Kg}$.

Table2. MIX PROPORTIONS

\begin{tabular}{|c|c|c|}
\hline S.NO & Ingredient & Quantity \\
\hline 01 & Cement & $423 \mathrm{~kg} / \mathrm{m}^{3}$ \\
\hline 02 & Water & $203 \mathrm{~L} / \mathrm{m}^{3}$ \\
\hline 03 & Fine Aggregate & $707.4 \mathrm{~kg} / \mathrm{m}^{3}$ \\
\hline 04 & Coarse Aggregate & $1062 \mathrm{~kg} / \mathrm{m}^{3}$ \\
\hline 05 & Chemical Admixture & $8.46 \mathrm{~kg} / \mathrm{m}^{3}$ \\
\hline \multicolumn{2}{|c|}{ W/C Ratio } & 0.48 \\
\hline & Mix Ratio & $1: 1.6: 2.6$ \\
\hline
\end{tabular}

MATERIALS REQUIRED FOR A BATCH OF M25 GRADE CONCRETE:

Volume Calculations:

Volume of 1 cube $=3.375 \times 10^{-3} \mathrm{~m}^{3}$

Volume of 1 cylinder

$=1.57 \times 10^{-3} \mathrm{~m}^{3}$

Volume of 1 beam

Total volume to be filled with concrete in one group $=6 \times\left(3.375 \times 10^{-3}\right)+6 \times\left(1.57 \times 10^{-3}\right)+4 \times(5.0 \times$ $\left.10^{-3}\right)=49.67 \times 10^{-3} \mathrm{~m}^{3}$

Total volume to be filled $=49.67 \times 10^{-3} \mathrm{~m}^{3} \times 7=$ $347.69 \times 10^{-3} \mathrm{~m}^{3}$

\section{Quantity Calculations:}

Cement required $=347.69 \times 10^{-3}$

$$
\mathrm{m}^{3} \times 423 \mathrm{~kg} / \mathrm{m}^{3}=147.07 \mathrm{~kg}
$$

Fine Aggregate $=147.07 \times 1.6=235.312 \mathrm{~kg}$

Coarse Aggregate $=147.07 \times 2.6 \quad=382.38 \mathrm{~kg}$

Water required $=147.07 \times 0.48=70.6 \mathrm{~kg}$

\section{Fibre quantity:}

Fibres are added at the rate of $0.5,0.75,1.0,1.25,1.5$, $2.0 \%$.

The quantities involved are tabulated as:

TABLE 3: Fibre Quantity Calculations

\begin{tabular}{|c|c|c|}
\hline S. NO & \% age of fibers & Wt. of fibre $(\mathrm{kg})$ \\
\hline 1 & 0 & 0 \\
\hline 2 & 0.5 & 1.92 \\
\hline 3 & 0.75 & 2.88 \\
\hline 4 & 1.0 & 3.8 \\
\hline 5 & 1.25 & 4.8 \\
\hline 6 & 1.5 & 5.72 \\
\hline 7 & 2 & 7.6 \\
\hline
\end{tabular}

Total weight of fibers used $=34 \mathrm{~kg}$

\section{TESTS ON MATERIALS \\ TESTS ON CEMENT}

\section{Standard Consistency}

Standard consistency is the water content at which hydration of cement is $100 \%$ complete. At standard consistency the vicat's plunger of $5 \mathrm{~mm}$ diameter will penetrate to a depth of 33 to $35 \mathrm{~mm}$ to the top of mould. Specifications from IS 4031:1988 Part IV were used. Standard consistency test for both OPC as well as admixture cement was carried out and the results are expressed as follows 
International Journal of Trend in Scientific Research and Development (IJTSRD) ISSN: 2456-6470

TABLE 4: Standard Consistency test of OPC (Max Grade 53)

\begin{tabular}{|c|c|c|c|c|c|c|}
\hline $\begin{array}{l}\text { S. } \\
\text { No. }\end{array}$ & $\begin{array}{l}\text { Wt. of } \\
\text { Cement } \\
\text { (gm) }\end{array}$ & $\begin{array}{l}\text { Wt. of } \\
\text { Water } \\
\text { added } \\
\end{array}$ & $\begin{array}{c}\text { \% age of water } \\
\text { added by wt. of } \\
\text { cement }\end{array}$ & $\begin{array}{l}\text { Penetration } \\
\text { (mm) }\end{array}$ & $\begin{array}{l}\text { Standard } \\
\text { Consistency }\end{array}$ & $\begin{array}{l}\text { Permissible } \\
\text { value as per } \\
\text { IS } 4031(\%) \\
\end{array}$ \\
\hline 01. & 400 & 116 & 29 & 20 & \multirow{3}{*}{$\begin{array}{l}\text { At } 31 \% \text { by } \\
\text { weight of } \\
\text { cement }\end{array}$} & \multirow{3}{*}{$\begin{array}{c}\text { Should be } \\
\text { about } 30 \% \text { by } \\
\text { wt of cement }\end{array}$} \\
\hline 02. & 400 & 120 & 30 & 30 & & \\
\hline 03. & 400 & 124 & 31 & 33 & & \\
\hline
\end{tabular}

TABLE 5: Standard Consistency test of OPC+ CaCl2 (2\% by weight of Cement)

\begin{tabular}{|c|c|c|c|c|c|c|}
\hline $\begin{array}{l}\text { S. } \\
\text { No. }\end{array}$ & $\begin{array}{l}\text { Wt. of } \\
\text { Cement+ } \\
\text { Cacl2 (gm) }\end{array}$ & $\begin{array}{l}\text { Wt. of } \\
\text { Water } \\
\text { added }\end{array}$ & $\begin{array}{l}\text { \% age of water } \\
\text { added by wt. } \\
\text { of cement }\end{array}$ & $\begin{array}{l}\text { Penetration } \\
\text { (mm) }\end{array}$ & $\begin{array}{l}\text { Standard } \\
\text { Consistency }\end{array}$ & $\begin{array}{c}\text { Permissible } \\
\text { value as per IS } \\
4031(\%)\end{array}$ \\
\hline 01. & 408 & 118.3 & 29 & 20 & \multirow{3}{*}{$\begin{array}{l}\text { At } 31 \% \text { by } \\
\text { weigh of } \\
\text { cement }\end{array}$} & \multirow{3}{*}{$\begin{array}{l}\text { Should be about } \\
30 \% \text { by wt of } \\
\text { cement }\end{array}$} \\
\hline 02. & 408 & 122.5 & 0 & 30 & & \\
\hline 03. & 408 & 126.5 & 31 & 33 & & \\
\hline
\end{tabular}

\section{Initial Setting Time Test}

Initial setting time of both OPC and admixture added OPC was carried out using Vicats apparatus. Specifications from IS 4031:1988 Part V and IS 12269:1988 were used.

TABLE 6: INITIAL SETTING TIME TEST

\begin{tabular}{|c|c|c|c|c|}
\hline $\begin{array}{c}\text { Weight of } \\
\text { water added } \\
(\mathbf{0 . 8 5} \mathrm{P}) \mathrm{gm}\end{array}$ & Admixture & $\begin{array}{c}\text { Penetration } \\
(\mathbf{m m})\end{array}$ & $\begin{array}{c}\text { Initial Setting } \\
\text { Time }\end{array}$ & Remarks \\
\hline 105.40 & NIL & 33 eS & al 70 minutes & $\begin{array}{c}\text { Should not be less than } 30 \\
\text { minutes }\end{array}$ \\
\hline 107.525 & $\mathrm{CaCl} 2 @ 2 \%$ & $33 \mathrm{eV}$ & 25 minutes & $\begin{array}{c}\text { Initial setting time decreased } \\
\text { to 64\% }\end{array}$ \\
\hline
\end{tabular}

\section{Final Setting Time}

TABLE 7: Final setting time test

\begin{tabular}{|c|c|c|c|c|}
\hline $\begin{array}{c}\text { Weight of } \\
\text { water added } \\
(0.85 \mathrm{P}) \text { gm }\end{array}$ & Admixture & Penetration & $\begin{array}{c}\text { Final } \\
\text { setting } \\
\text { Time }\end{array}$ & Remarks \\
\hline 105.40 & NIL & $\begin{array}{c}\text { Final setting time needle } \\
\text { makes an impression but } \\
\text { collar fails to do so }\end{array}$ & $3 \mathrm{~h} 50 \mathrm{~m}$ & $\begin{array}{c}\text { Should not be more than } \\
10 \text { hours }\end{array}$ \\
\hline 105.4 & $\mathrm{CaCl} 2 @ 2 \%$ & $\begin{array}{c}\text { Final setting time needle } \\
\text { makes an impression but } \\
\text { collar fails to do so }\end{array}$ & $2 \mathrm{~h} 10 \mathrm{~m}$ & $\begin{array}{c}\text { Final setting time has } \\
\text { decreased by } 45 \%\end{array}$ \\
\hline
\end{tabular}

\section{Specific Gravity}

Specific gravity has been calculated using density bottle method. Specific gravity is given by

$\mathrm{G}=(\mathrm{W} 2-\mathrm{w} 1) /[(\mathrm{W} 2-\mathrm{W} 1)-(\mathrm{W} 3-\mathrm{W} 4)]$

Where $\quad$ W1 $=$ Wt. of dry density bottle with lid

$\mathrm{W} 2=\mathrm{Wt}$. of bottle with lid \& cement

W3 = Wt. of density bottle with lid, cement \& water

$\mathrm{W} 4=\mathrm{Wt}$. of density bottle with lid \& water 
International Journal of Trend in Scientific Research and Development (IJTSRD) ISSN: 2456-6470

TABLE 8: Specific Gravity Test of Cement

\begin{tabular}{|c|c|c|c|c|c|}
\hline SAMIPLE NO. & W1 & W2 & W3 & W4 & G \\
\hline 1 & 30.75 & 40.74 & 87.98 & 81.04 & 3.2 \\
\hline 2 & 30.75 & 40.59 & 87.75 & 80.80 & 3.18 \\
\hline 3 & 30.75 & 42.75 & 88.91 & 80.80 & 3.08 \\
\hline
\end{tabular}

Result: Average value of Specific gravity $=3.15$

\section{Fineness Test}

TABLE 9: FINENESS TEST RESULTS

\begin{tabular}{|c|c|c|c|c|c|c|}
\hline S. No. & $\begin{array}{c}\text { Wt. of } \\
\text { cement } \\
\text { (gm) }\end{array}$ & $\begin{array}{c}\text { Wt. of residue } \\
\text { after } \mathbf{1 5} \text { min of } \\
\text { shaking (gm) }\end{array}$ & $\begin{array}{c}\text { \% age } \\
\text { residue }\end{array}$ & $\begin{array}{c}\text { Avg. } \\
\text { value(\%) }\end{array}$ & $\begin{array}{c}\text { Permissible } \\
\text { values as per IS } \\
4031(\%)\end{array}$ & Remarks \\
\hline 1. & 100 & 6 & 6 & & Up to 10 & Satisfies the fineness test \\
\hline 2. & 100 & 5 & 5 & 5.33 & & \\
\hline 3. & 100 & 5 & 5 & & & \\
\hline
\end{tabular}

\section{Tests on Fine Aggregates}

1. Sieve analysis of fine aggregates

Weight of Sample: - $1000 \mathrm{gm}$

Table 10: Sieve Analysis of Fine Aggregates

\begin{tabular}{|c|c|c|c|c|c|}
\hline S. No. & IS Sieve Size & $\begin{array}{c}\text { Weight } \\
\text { Retained } \\
(\text { gm) }\end{array}$ & $\begin{array}{c}\text { Cumulative } \\
\text { Weight } \\
\text { Retained } \\
(\text { gm) }\end{array}$ & $\begin{array}{c}\text { Cumulative } \\
\text { \% age } \\
\text { Wt.Retained }\end{array}$ & $\begin{array}{c}\text { Cumulative } \\
\text { \% age } \\
\text { Wt.Passing }\end{array}$ \\
\hline 1. & $4.75 \mathrm{~mm}$ & 15 & 15 Ient & 1.5 & 98.5 \\
\hline 2. & $2.36 \mathrm{~mm}$ & 5.28 & 20.28 & 2.03 & 97.97 \\
\hline 3. & $1.2 \mathrm{~mm}$ & 555 & 575.28 & 57.53 & 42.47 \\
\hline 4. & $600 \mu$ & 330 & 905.28 & 90.53 & 9.47 \\
\hline 5. & $300 \mu$ & 51.7 & 956.98 & 95.69 & 4.31 \\
\hline 6. & $150 \mu$ & 43 & 999.98 & 99.99 & 0.01 \\
\hline 7. & Pan & 0.02 & 1000 & 100 & 0 \\
\hline
\end{tabular}

Fineness Modulus $=\Sigma$ Cumulative \%age wt. retained $/ 100$ $=447.27 / 100=4.47$

As per IS 383-1970, the sand falls in zone I.

\section{SPECIFIC GRAVITY TEST OF FINE AGGREGATE}

Specific gravity has been calculated using density bottle method. Specific gravity is given by

$$
\mathrm{G}=(\mathrm{W} 2-\mathrm{W} 1) /[(\mathrm{W} 2-\mathrm{W} 1)-(\mathrm{W} 3-\mathrm{W} 4)]
$$

Where $\quad \mathrm{W} 1=\mathrm{Wt}$. of dry density bottle with lid

$\mathrm{W} 2=\mathrm{Wt}$. of bottle with lid \& cement

$\mathrm{W} 3=\mathrm{Wt}$. of density bottle with lid, cement \& water

W4 = Wt. of density bottle with lid \& water

Table 11: Specific gravity test results of fine aggregates

\begin{tabular}{|c|c|c|c|c|c|}
\hline Sample. No. & W1 (gm) & W2 $(\mathrm{gm})$ & W3 (gm) & W4(gm) & Sp.Gravity \\
\hline 01. & 681.1 & 820.7 & 1635.5 & 1549 & 2.62 \\
\hline 02. & 681.1 & 830.5 & 1644.2 & 1549 & 2.77 \\
\hline 03. & 681.1 & 840.5 & 1650 & 1549 & 2.68 \\
\hline
\end{tabular}

Average Value of Specific Gravity $=2.62+2.77+2.68 / 3$

$$
=2.70
$$


International Journal of Trend in Scientific Research and Development (IJTSRD) ISSN: 2456-6470

\section{TESTS ON COARSE AGGREGATES}

1. Sieve Analysis of Coarse Aggregates Size: - Max 20mm

Weight of Sample $=3000 \mathrm{gms}$

Table 12: Sieve Analysis of Coarse Aggregates

\begin{tabular}{|c|c|c|c|c|c|}
\hline S. No. & $\begin{array}{c}\text { IS Sieve Size } \\
(\mathbf{m m})\end{array}$ & $\begin{array}{c}\text { Wt.retained } \\
(\text { gm) }\end{array}$ & $\begin{array}{c}\text { \% age } \\
\text { Wt.retained }\end{array}$ & $\begin{array}{c}\text { Cumulative } \\
\text { \% age } \\
\text { Wt.retaind }\end{array}$ & $\begin{array}{c}\text { \% age wt. } \\
\text { passing }\end{array}$ \\
\hline 01. & 80 & 0 & 0 & 0 & 100 \\
\hline 02. & 63 & 0 & 0 & 0 & 100 \\
\hline 03. & 40 & 0 & 0 & 0 & 100 \\
\hline 04. & 20 & 251.66 & 8.38 & 8.38 & 91.62 \\
\hline 05. & 12.5 & 1939.16 & 64.64 & 73.02 & 26.98 \\
\hline 06. & 4.75 & 809.18 & 26.97 & 100 & 0 \\
\hline 07. & 2.36 & - & - & - & - \\
\hline 08. & Pan & - & - & - & - \\
\hline
\end{tabular}

Fineness Modulus $\quad=\Sigma$ Cumulative $\%$ age wt. retained $/ 100$

$$
=1.82
$$

FIG 4: SIEVE ANALYSIS OF COARSE AGGREGATES (L) AND FINE AGGREGATES(R)

\section{SPECIFIC GRAVITY TEST OF COARSE AGGREGATE}

Specific gravity has been calculated using density bottle method. Specific gravity is given by

$\mathrm{G}=(\mathrm{W} 2-\mathrm{W} 1) /[(\mathrm{W} 2-\mathrm{W} 1)-(\mathrm{W} 3-\mathrm{W} 4)]$

Where $\quad \mathrm{W} 1=\mathrm{Wt}$. of dry density bottle with lid

$\mathrm{W} 2=\mathrm{Wt}$. of bottle with lid \& cement

W3 = Wt. of density bottle with lid, cement \& water

W4 = Wt. of density bottle with lid \& water

TABLE 13: Specific gravity test results of Coarse aggregates

\begin{tabular}{|c|c|c|c|c|c|}
\hline S. No. & W1 (gm) & W2 (gm) & W3 (gm) & W4(gm) & Sp.Gravity \\
\hline 01. & 680.5 & 1000.5 & 1784 & 1583.5 & 2.67 \\
\hline 02. & 680.5 & 1030.5 & 1804.5 & 1583.5 & 2.71 \\
\hline 03. & 680.5 & 1040.5 & 1810 & 1583.5 & 2.70 \\
\hline
\end{tabular}

Average Value of Specific Gravity $=2.70$ 


\section{MECHANICAL TESTING OF COARSE AGGREGATES}

\section{Aggregate Crushing Value}

$3 \mathrm{~kg}$ of aggregate passing $12.5 \mathrm{~mm}$ and retained on $10 \mathrm{~mm}$ Sieve in a dry Condition is filled into the standard cylindrical measure in 3 layers. The apparatus with the sample in position is loaded uniformly up to a load of $40 \mathrm{t}$ in 10 minutes time. After releasing the load, whole of the material is removed and sieved on a $2.36 \mathrm{~mm}$ IS Sieve. The fraction passing through it is weighed.

Aggregate Crushing value $=\mathrm{Wt}$. of fraction passing $2.36 \mathrm{~mm}$ sieve/wt.of sample

$$
\begin{aligned}
& =720 / 3000 \\
& =26 \%
\end{aligned}
$$

Result: Aggregate Crushing value is less than $45 \%$ which is prescribed limit for coarse aggregate used for concrete.

\section{Aggregate impact value}

400 gms of the sample passing through $12.5 \mathrm{~mm}$ sieve and retained on $10 \mathrm{~mm}$ sieve is filled into a cylinder steel cup. The sample is subjected to 15 blows of a $14 \mathrm{~kg}$ hammer, raised to a height of $380 \mathrm{~mm}$. The crushed aggregate is removed on $2.36 \mathrm{~mm}$ IS Sieve.

Aggregate Impact Value $=\mathrm{Wt}$. of fraction passing $2.36 \mathrm{~mm}$ IS Sieve / Wt. of sample

$$
\begin{aligned}
& =59 / 400 \\
& =14.7 \%
\end{aligned}
$$

Result: Aggregate is strong and the value falls below the max. Prescribed limit of $30 \%$

\section{Aggregate abrasion value}

This test is carried in Los Angeles abrasion testing machine. According to the test specifications 5000gm of the aggregate passing $20 \mathrm{~mm}$ sieve and retained on $10 \mathrm{~mm}$ sieve, the aggregate falls in grade B. No. of spheres taken $=11$

Wt. of aggregates $=5000 \mathrm{gm}$

Wt. of aggregates retained on $1.70 \mathrm{~mm}$ IS Sieve after the test $=4243 \mathrm{gm}$

Loss in weight due to wear $=5000-4243=757 \mathrm{gm}$ Los Angeles abrasion value, $\%=757 / 5000=15 \%$

The maximum Specified value of abrasion for cement concrete pavements surface course is $30 \%$. Hence test result is satisfactory

\section{Shape Tests}

Shape tests

Shape tests of coarse aggregates were carried out using metal thickness gauge for flakiness index and metal length for elongation index. The flakiness index of aggregate is the percentage by weight of particles in it whose least dimension (thickness) is less than three-fifth of their mean dimension. The elongation index on an aggregate is the percentage by weight of particles whose greatest dimension (length) is greater than 1.8 times their mean dimension. The tests are not applicable to sizes smaller than $6.3 \mathrm{~mm}$.

The flakiness test was conducted by using a metal thickness gauge. A sufficient quantity of aggregate was taken such that a minimum number of 200 pieces of any fraction can be tested. The flakiness index is taken as the total weight of the material passing the various thickness gauges expressed as percentage of the total weight of the sample taken

\begin{tabular}{l} 
T3able14. Flakiness Index \\
\begin{tabular}{|c|c|c|}
\hline S.NO & Sieve No.(mm) & Wt. Retained \\
\hline 1 & 31.5 & 0 \\
\hline 2 & 25 & 82 \\
\hline 3 & 20 & 457 \\
\hline 4 & 16 & 2510 \\
\hline 5 & 12.5 & 1528 \\
\hline 6 & 10 & 200 \\
\hline 7 & 6.3 & 230 \\
\hline 8 & 4.75 & - \\
\hline
\end{tabular} \\
\hline
\end{tabular}

Flakiness value $=(145+185+252+82+25) \times 100 / 1969$

\section{Table15. Elongation index}

\begin{tabular}{|c|c|c|c|}
\hline \multicolumn{2}{|c|}{ Sieve Sive } & \multirow{2}{*}{$\begin{array}{c}\text { Wt. of } \\
\text { sample } \\
\text { Passing }\end{array}$} & $\begin{array}{c}\text { Wt. retained } \\
\text { on the } \\
\text { respective } \\
\text { gauge (gms) }\end{array}$ \\
\hline $\mathbf{2 5}$ & $\mathbf{2 0}$ & $\mathbf{4 5 7}$ & $\mathbf{9 8}$ \\
\hline $\mathbf{2 0}$ & $\mathbf{1 6}$ & $\mathbf{5 0 0}$ & $\mathbf{1 6 7}$ \\
\hline $\mathbf{1 6}$ & $\mathbf{1 2 . 5}$ & $\mathbf{5 0 0}$ & $\mathbf{2 6 8}$ \\
\hline $\mathbf{1 2 . 5}$ & $\mathbf{1 0}$ & $\mathbf{2 3 0}$ & $\mathbf{1 6 2}$ \\
\hline $\mathbf{1 0}$ & $\mathbf{6 . 3}$ & $\mathbf{2 0 0}$ & $\mathbf{1 9 3}$ \\
\hline Elongation & value $=$ & $\begin{array}{l}(98+167+268+162+193) \\
\end{array}$ \\
& $=47.05 \%$ & \\
&
\end{tabular}

The presence of elongated particles in excess of 10 to $15 \%$ is generally considered undesirable but no recognized limits are laid down. 


\section{TESTING OF SAMPLES}

Various tests conducted on samples of concrete were:

3. Flexure Test

1. Slump Test (On Fresh Concrete)

4. Split Tensile Test

2. Compression Test

5. Water Absorption Test

The results of all these tests are categorically shown as

1. Slump test

It is observed that the workability (Slump) of concrete decreases as fibres content increases. The initial slump of control concrete was $50 \mathrm{~mm}$ and it was reduced to $17 \mathrm{~mm}$ at $1.0 \%$ fibres and at $2 \%$, no workability was observed.

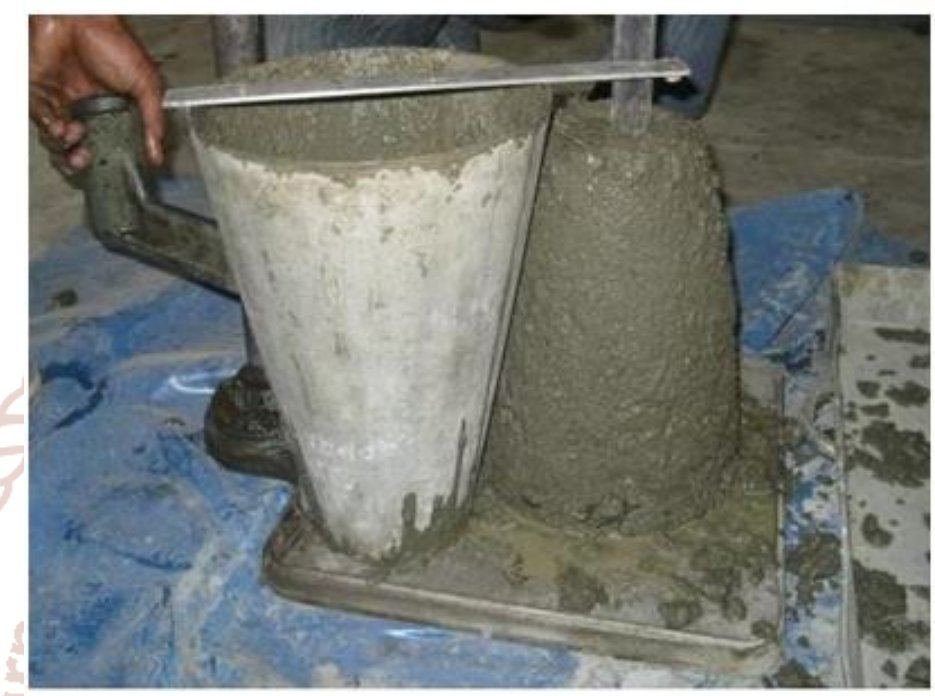

\section{FIG 6: SLUMP TEST}

TABLE 16: Slump values corresponding to different \%ages of Fibre added

\begin{tabular}{|c|c|c|}
\hline S. No. & Percentage of fiber added & Slump value $(\mathrm{mm})$ \\
\hline 01 & 0 & $50 \mathrm{~mm}$ \\
\hline 02 & $0.5 \%$ & $30 \mathrm{~mm}$ \\
\hline 03 & $0.75 \%$ & $25 \mathrm{~mm}$ \\
\hline 04 & $1 \%$ & $17 \mathrm{~mm}$ \\
\hline 05 & $1.25 \%$ & $10 \mathrm{~mm}$ \\
\hline 06 & $1.5 \%$ & $7 \mathrm{~mm}$ \\
\hline 07 & $2 \%$ & 0 \\
\hline
\end{tabular}

2. Water Absorption Test

TABLE 17: Water absorption test results

\begin{tabular}{|c|c|c|c|c|c|}
\hline S. No. & \%age of fibre & $\begin{array}{c}\text { Dry weight } \\
\text { of Cube }(\mathrm{gm})\end{array}$ & $\begin{array}{c}\text { Weight of cube }+ \\
\text { water }(\mathrm{gm})\end{array}$ & $\begin{array}{c}\text { Water absorbed } \\
(\mathrm{gm})\end{array}$ & $\begin{array}{c}\text { Percentage water } \\
\text { absorption }\end{array}$ \\
\hline 01 & 0 & 8382 & 8500 & 118 & $1.41 \%$ \\
\hline 02 & $0.5 \%$ & 8400 & 8490 & 90 & $1.07 \%$ \\
\hline 03 & $0.75 \%$ & 8472 & 8557 & 85 & $1.00 \%$ \\
\hline 04 & $1 \%$ & 8510 & 8583 & 73 & $0.85 \%$ \\
\hline 05 & $1.25 \%$ & 8600 & 8600 & 60 & $0.69 \%$ \\
\hline 06 & $1.5 \%$ & 8710 & 8745 & 35 & $0.40 \%$ \\
\hline 07 & $2 \%$ & 8800 & 8821 & 21 & $0.23 \%$ \\
\hline
\end{tabular}


International Journal of Trend in Scientific Research and Development (IJTSRD) ISSN: 2456-6470

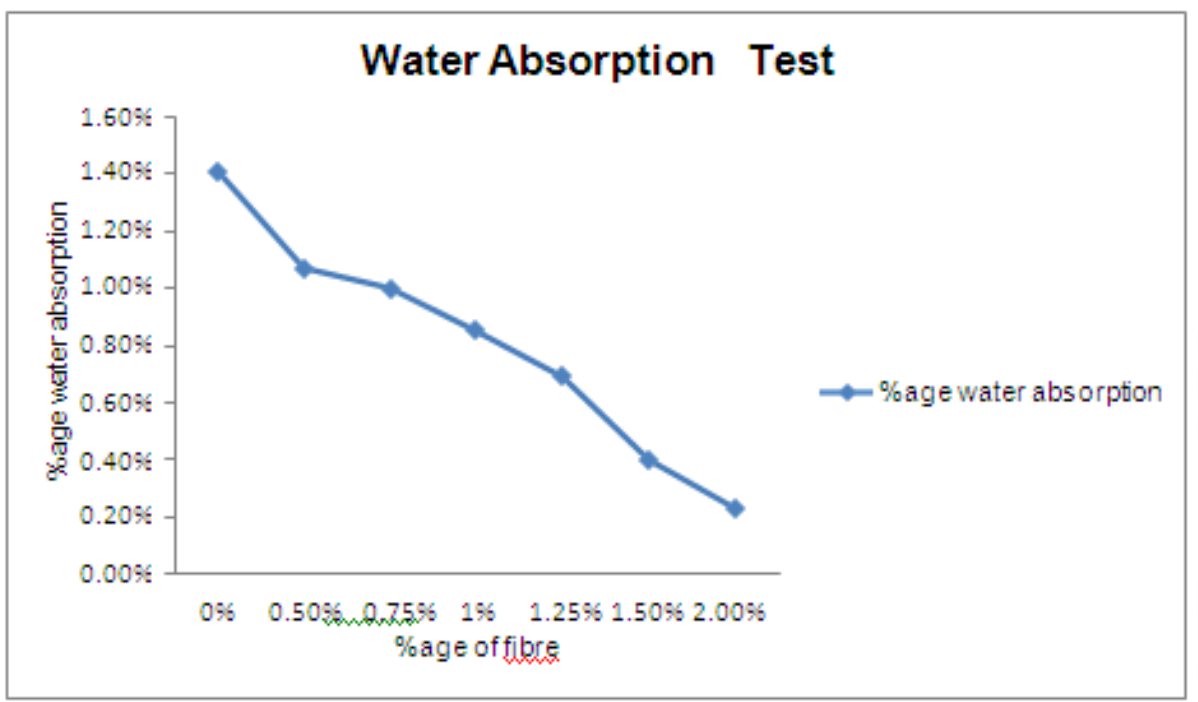

\section{CUBE COMPRESSION TESTS}

$>3$ day compressive strength (150mm cube)

TABLE18. 3-Days Compressive strength test

\begin{tabular}{|c|c|c|c|c|c|c|c|}
\hline S. No. & $\begin{array}{c}\text { Date of } \\
\text { Casting }\end{array}$ & Date of Testing & $\begin{array}{c}\text { \%age Of } \\
\text { Fibres }\end{array}$ & $\begin{array}{c}\text { Trial 1 } \\
\text { Load in } \\
\text { KN }\end{array}$ & $\begin{array}{c}\text { Trail 2 } \\
\text { Load in } \\
\text { KN }\end{array}$ & $\begin{array}{c}\text { Avg } \\
\text { Load in } \\
\text { KN }\end{array}$ & $\begin{array}{c}\text { Avg Comp } \\
\text { strength in } \\
\text { N/mm² }\end{array}$ \\
\hline 01 & $14-04-15$ & $17-04-15$ & $0 \%$ & 380 & 370 & 375 & 16.66 \\
\hline 02 & $14-04-15$ & $17-04-15$ & $0.5 \%$ & 395 & 385 & 390 & 17.33 \\
\hline 03 & $18-04-15$ & $21-04-15$ & $0.75 \%$ & 400 & 400 & 400 & 17.77 \\
\hline 04 & $22-04-15$ & $25-04-15$ & $1 \%$ & 415 & 425 & 420 & 18.66 \\
\hline 05 & $08-05-15$ & $11-04-15$ & $1.25 \%$ & 425 & 425 & 425 & 18.88 \\
\hline 06 & $28-05-15$ & $31-05-15$ & $1.5 \%$ & 370 & 410 & 390 & 17.33 \\
\hline 07 & $04-06-15$ & $07-06-15$ & $2 \%$ & 320 & 320 & 320 & 14.22 \\
\hline
\end{tabular}

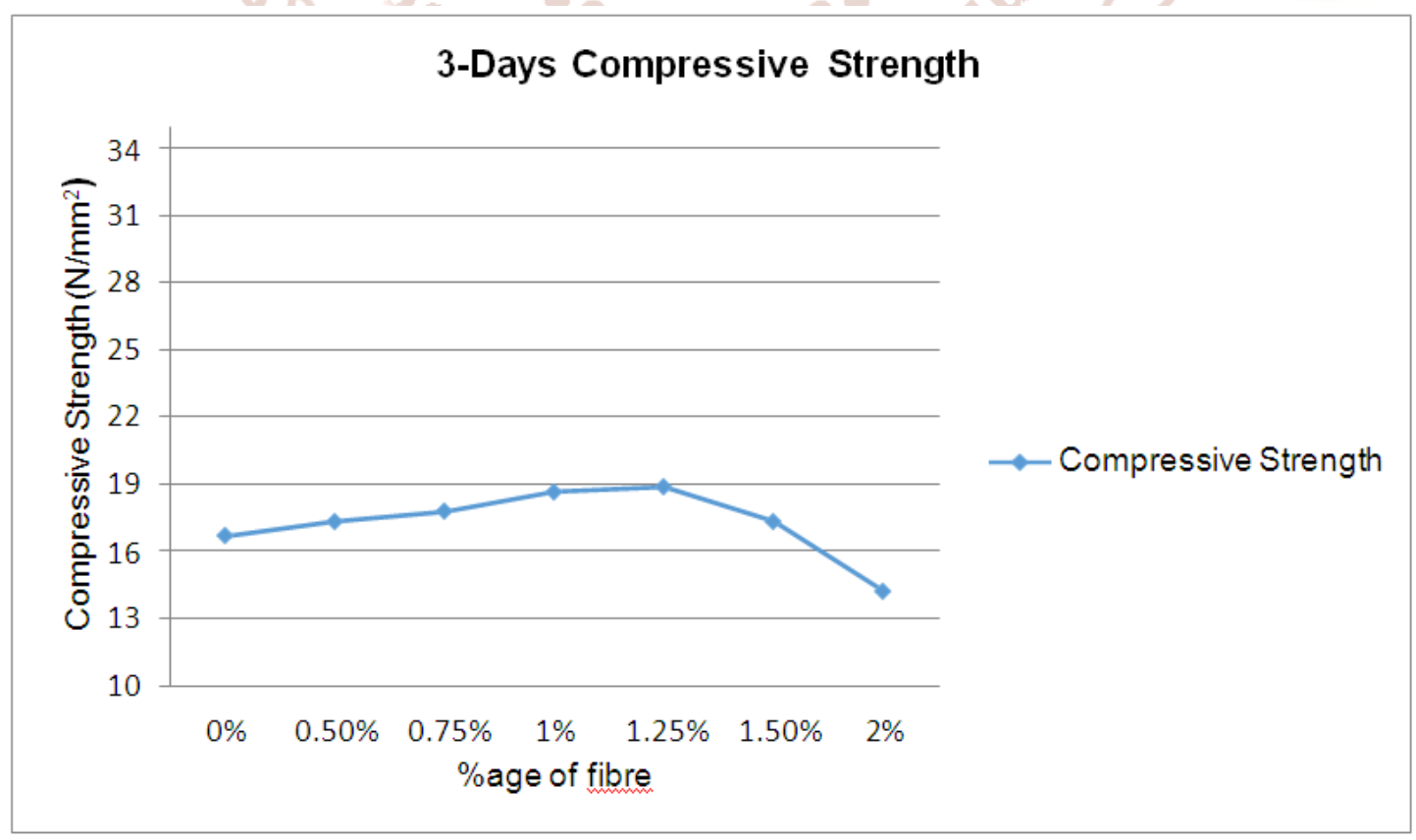

GRAPH 1: 3 DAY COMPRESSIVE STRENGTH OF SFRC 


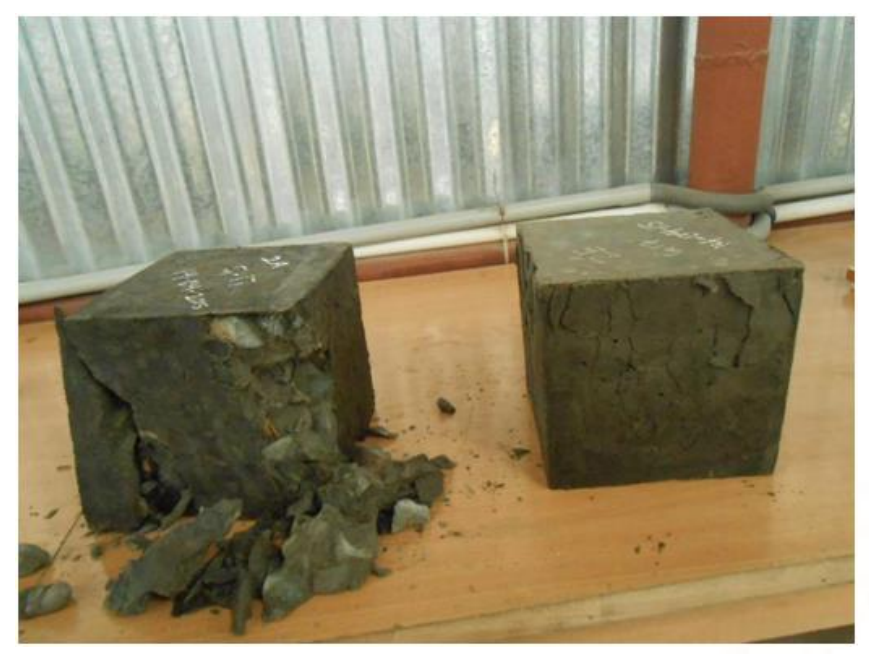

FIG 7: COMPARISON OF COMPRESSION FAILURE IN ORDINARY CONCRETE (L) AND FRC (R)@ $1.25 \%$ AFTER 3 DAYS

7 day compressive strength

TABLE 19 : 7 Day compressive strength

\begin{tabular}{|c|c|c|c|c|c|c|c|}
\hline S. No. & $\begin{array}{c}\text { Date of } \\
\text { Casting }\end{array}$ & $\begin{array}{c}\text { Date of } \\
\text { Testing }\end{array}$ & $\begin{array}{c}\text { \%age Of } \\
\text { Fibres }\end{array}$ & $\begin{array}{c}\text { Trial 1 Load } \\
\text { in KN }\end{array}$ & $\begin{array}{c}\text { Trail 2 } \\
\text { Load in } \\
\text { KN }\end{array}$ & $\begin{array}{c}\text { Average } \\
\text { Load } \\
\text { inKN }\end{array}$ & $\begin{array}{c}\text { Avg Comp } \\
\text { strength } \\
\text { N/mm }\end{array}$ \\
\hline 01 & $14-04-15$ & $21-04-15$ & $0 \%$ Int & Ong5 OU & 480 & 487.5 & 21.66 \\
\hline 02 & $14-04-15$ & $21-04-15$ & $0.5 \%$ & 595 & 595 & 595 & 26.44 \\
\hline 03 & $18-04-15$ & $25-04-15$ & $0.75 \%$ & 580 & 540 & 600 & 26.66 \\
\hline 04 & $22-04-15$ & $29-04-15$ & $1 \%$ & 610 & 630 & 620 & 27.55 \\
\hline 05 & $08-05-15$ & $15-04-15$ & $1.25 \%$ & 610 & 650 & 630 & 28 \\
\hline 06 & $28-05-15$ & $04-06-15$ & $1.5 \%$ & 590 & 590 & 590 & 26.22 \\
\hline 07 & $04-06-15$ & $11-06-15$ & $2 \%$ & 495 & 505 & 500 & 22.22 \\
\hline
\end{tabular}

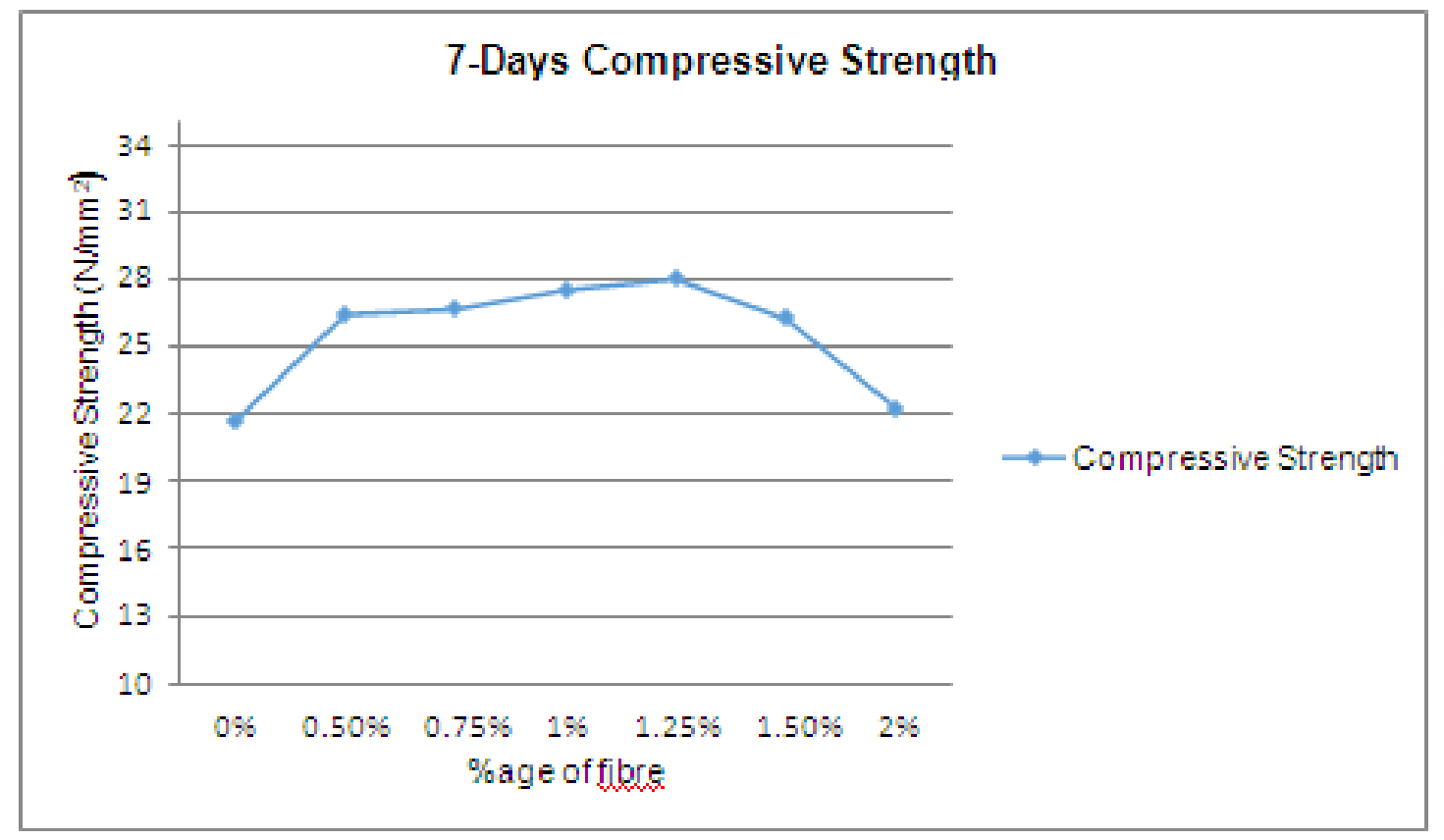

GRAPH 2: 7 DAY COMPRESSIVE STRENGTH OF SFRC 
International Journal of Trend in Scientific Research and Development (IJTSRD) ISSN: 2456-6470

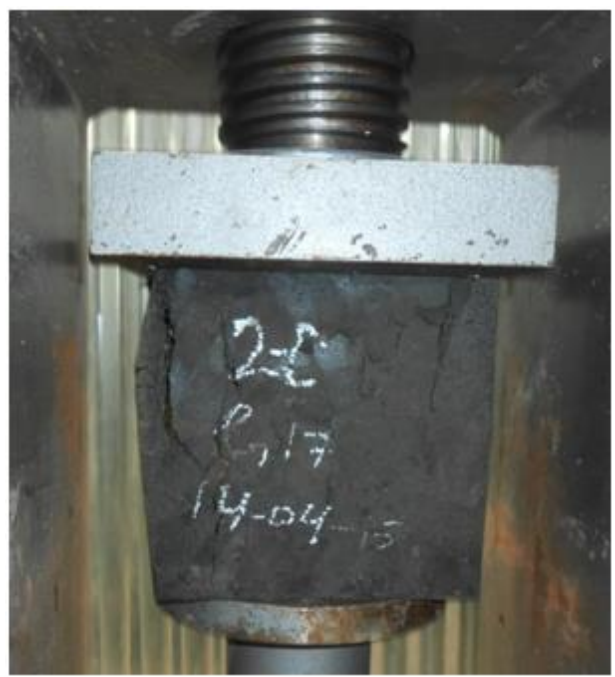

FIG 8: COMPRESSION FAILURE IN FRC @ 1.25\% AFTER 7 DAYS

28 days compressive strength

TABLE 20. 28-Days Compressive strength test

\begin{tabular}{|c|c|c|c|c|c|c|c|}
\hline S.No. & $\begin{array}{c}\text { Date of } \\
\text { Casting }\end{array}$ & $\begin{array}{c}\text { Date of } \\
\text { Testing }\end{array}$ & $\begin{array}{c}\% \text { Fibres } \\
\text { Fibre }\end{array}$ & $\begin{array}{c}\text { Trial 1 } \\
\text { Load in } \\
\mathrm{KN}\end{array}$ & $\begin{array}{c}\text { Trail 2 } \\
\text { Load in } \\
\mathrm{KN}\end{array}$ & $\begin{array}{c}\text { Avg } \\
\text { Load in } \\
\mathrm{KN}\end{array}$ & $\begin{array}{c}\text { Avg Comp } \\
\text { strength in } \\
\text { N/mm }{ }^{2}\end{array}$ \\
\hline 01 & $14-04-15$ & $12-05-15$ & $0 \%$ & 590 & 610 & 600 & 26.66 \\
\hline 02 & $14-04-15$ & $12-05-15$ & $0.5 \%$ d & 650 & 690 & 670 & 29.77 \\
\hline 03 & $18-04-15$ & $16-05-15$ & $0.75 \%$ & 840 & 810 & 700 & 31.11 \\
\hline 04 & $22-04-15$ & $20-05-15$ & $1 \%$ & 720 & 720 & 720 & 32 \\
\hline 05 & $08-05-15$ & $05-06-15$ & $1.25 \%$ & 750 & 720 & 735 & 32.66 \\
\hline 06 & $28-05-15$ & $25-06-15$ & $1.5 \%$ & 695 & 705 & 700 & 31.11 \\
\hline 07 & $04-06-15$ & $02-07-15$ & $2 \%$ & 660 & 660 & 660 & 29.33 \\
\hline
\end{tabular}

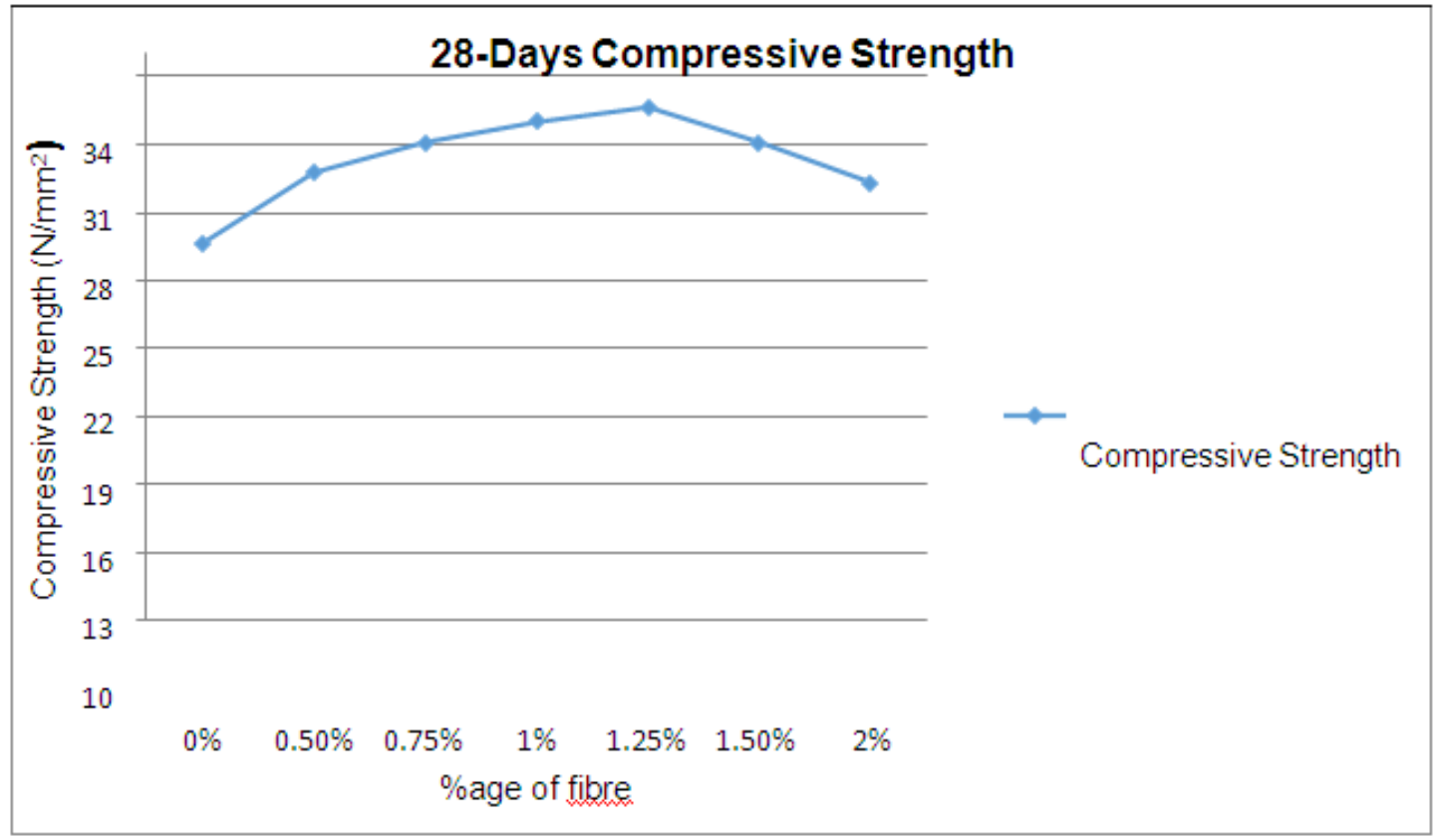

GRAPH 3: 28 DAY COMPRESSIVE STRENGTH OF SFRC 


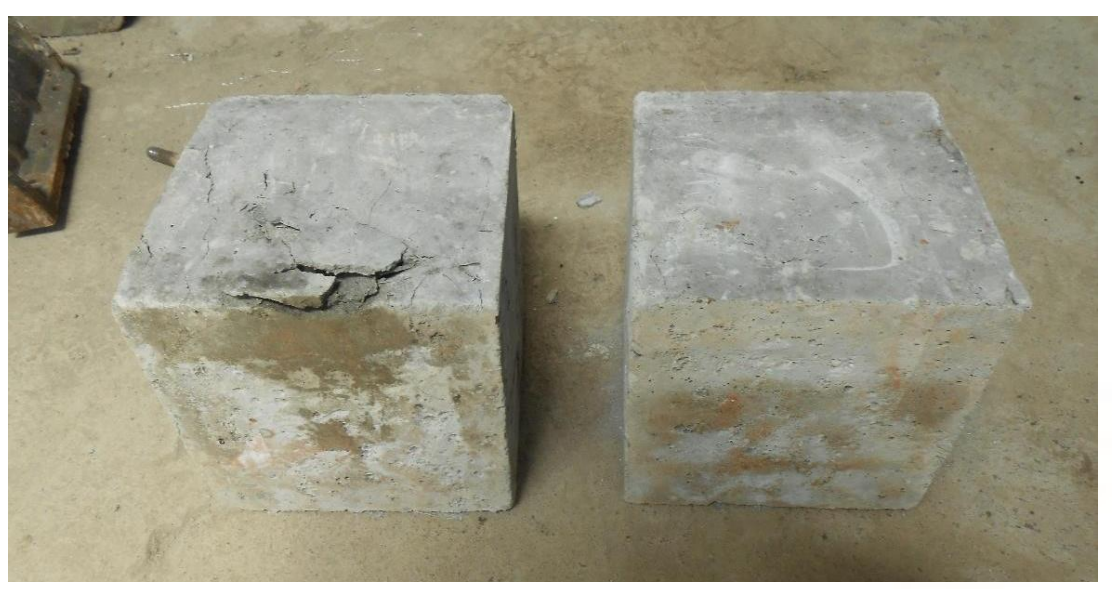

FIG 9: COMPARISON OF COMPRESSION FAILURE IN ORDINARY CONCRETE (L) AND FRC (R) @ 1.25\% AFTER 28 DAYS

$>$ Comparison of Compressive Strength at 3,7 and 28 days

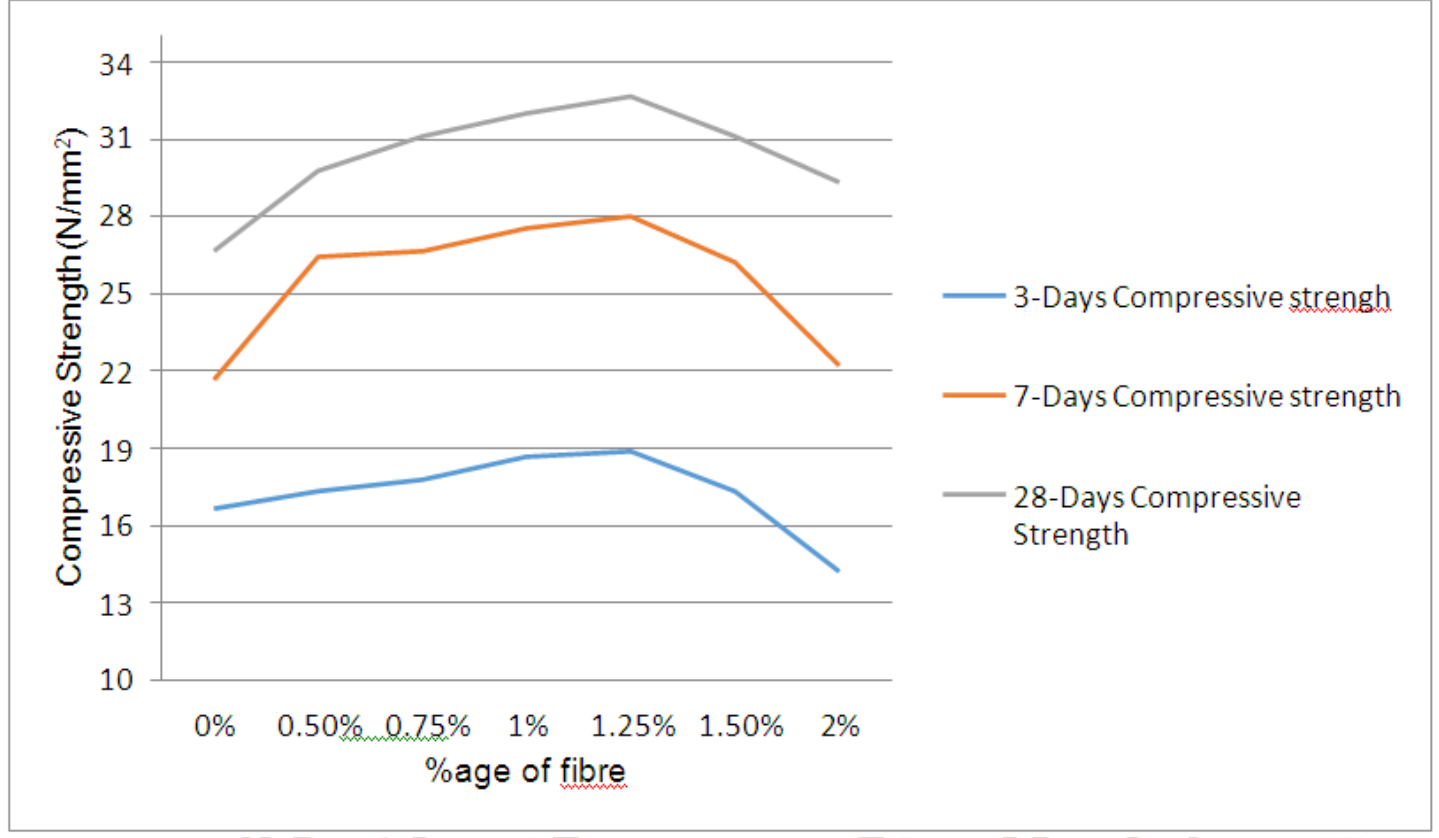

GRAPH 4: Comparison of Compressive Strength at 3,7 and 28 days

4. TENSILE STRENGTH

TABLE 21: 3-Days split tensile strength test

\begin{tabular}{|c|c|c|c|c|c|}
\hline S. No & $\begin{array}{c}\text { Date of } \\
\text { Casting }\end{array}$ & $\begin{array}{c}\text { Date of } \\
\text { Testing }\end{array}$ & \%age of Fibres & $\begin{array}{c}\text { Avg. Load } \\
\text { in KN }\end{array}$ & $\begin{array}{c}\text { Avg. Split } \\
\text { Tensile Strength } \\
\text { in N/mm }\end{array}$ \\
\hline 01 & $14-04-15$ & $17-04-15$ & $0 \%$ & 25 & 0.79 \\
\hline 02 & $15-04-15$ & $18-04-15$ & $0.5 \%$ & 35 & 1.11 \\
\hline 03 & $18-04-15$ & $21-04-15$ & $0.75 \%$ & 45 & 1.43 \\
\hline 04 & $22-04-15$ & $25-04-15$ & $1 \%$ & 60 & 1.90 \\
\hline 05 & $08-05-15$ & $11-04-15$ & $1.25 \%$ & 70 & 2.22 \\
\hline 06 & $28-05-15$ & $31-05-15$ & $1.5 \%$ & 55 & 1.75 \\
\hline 07 & $04-06-15$ & $07-06-15$ & $2 \%$ & 45 & 1.43 \\
\hline
\end{tabular}


International Journal of Trend in Scientific Research and Development (IJTSRD) ISSN: 2456-6470

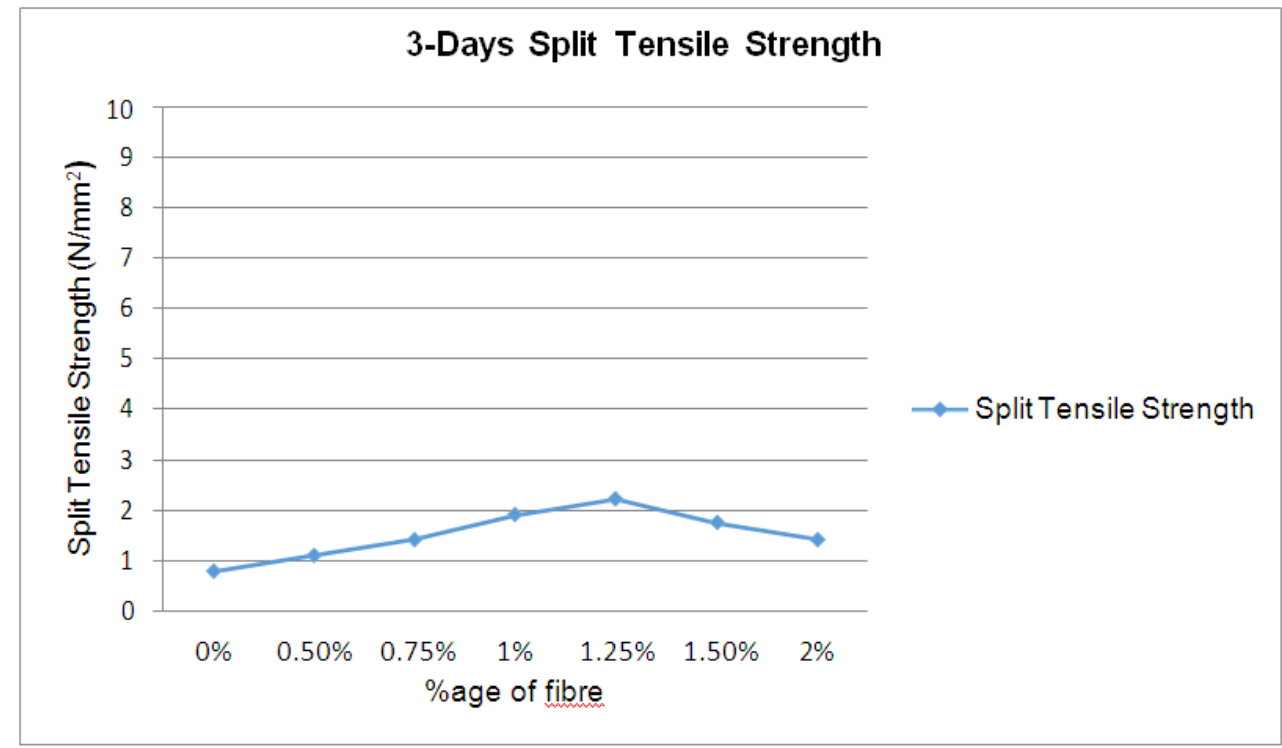

GRAPH 5: 3 DAY SPLIT TENSILE STRENGTH

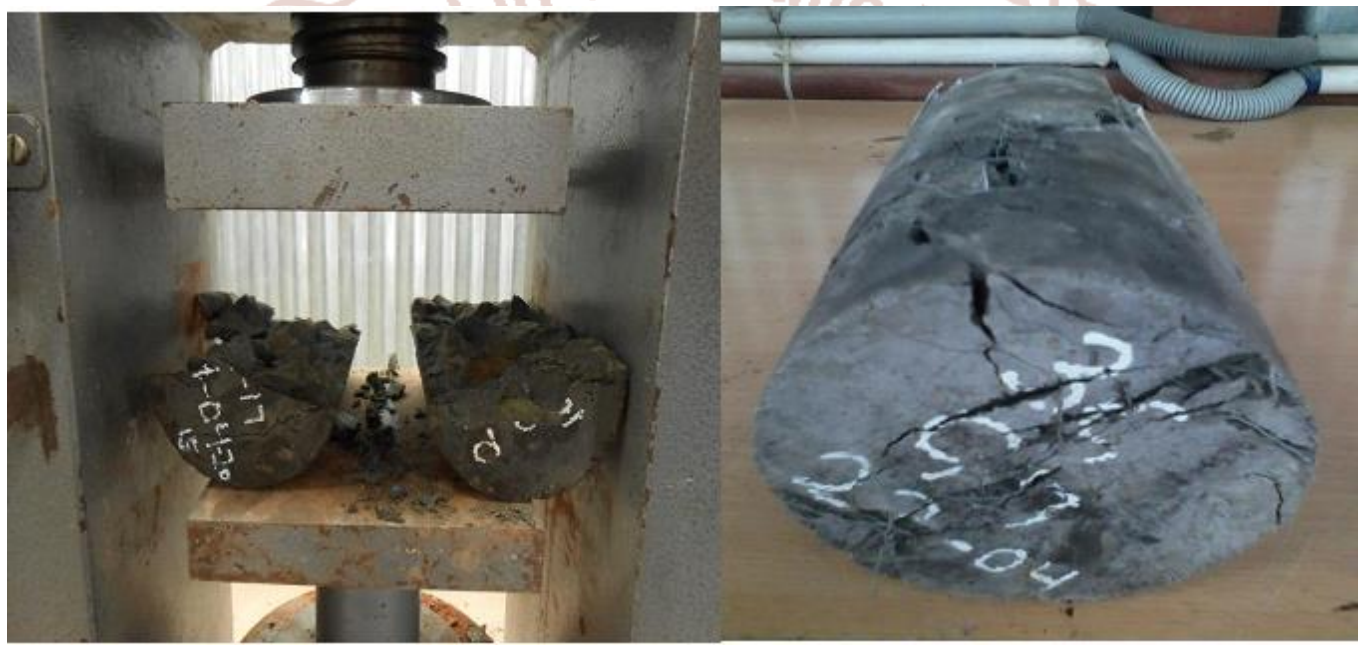

FIG 12: BEHAVIOUR OF CYLINDER SPECIMENS WITH FIBRES (LEFT) AND WITHOUTN FIBRES (RIGHT) SUBJECTED TO SPLIT TENSILE STRENGTH TEST AFTER 3 DAYS

7 day split tensile strength

TABLE 22: 7-Days split tensile strength test results

\begin{tabular}{|c|c|c|c|c|c|}
\hline S.No & $\begin{array}{c}\text { Date of } \\
\text { Casting }\end{array}$ & $\begin{array}{c}\text { Date of } \\
\text { Testing }\end{array}$ & $\begin{array}{c}\text { \%age of } \\
\text { Fibres }\end{array}$ & $\begin{array}{c}\text { Avg. Load in } \\
\text { KN }\end{array}$ & $\begin{array}{c}\text { Avg. Split Tensile } \\
\text { Strength in N/mm }\end{array}$ \\
\hline 01 & $14-04-15$ & $21-04-15$ & $0 \%$ & 45 & 1.43 \\
\hline 02 & $14-04-15$ & $22-04-15$ & $0.5 \%$ & 75 & 2.38 \\
\hline 03 & $18-04-15$ & $25-04-15$ & $0.75 \%$ & 78 & 2.48 \\
\hline 04 & $22-04-15$ & $29-04-15$ & $1 \%$ & 80 & 2.54 \\
\hline 05 & $08-05-15$ & $15-04-15$ & $1.25 \%$ & 85 & 2.70 \\
\hline 06 & $28-05-15$ & $04-06-15$ & $1.5 \%$ & 80 & 2.54 \\
\hline 07 & $04-06-15$ & $11-06-15$ & $2 \%$ & 60 & 1.90 \\
\hline
\end{tabular}




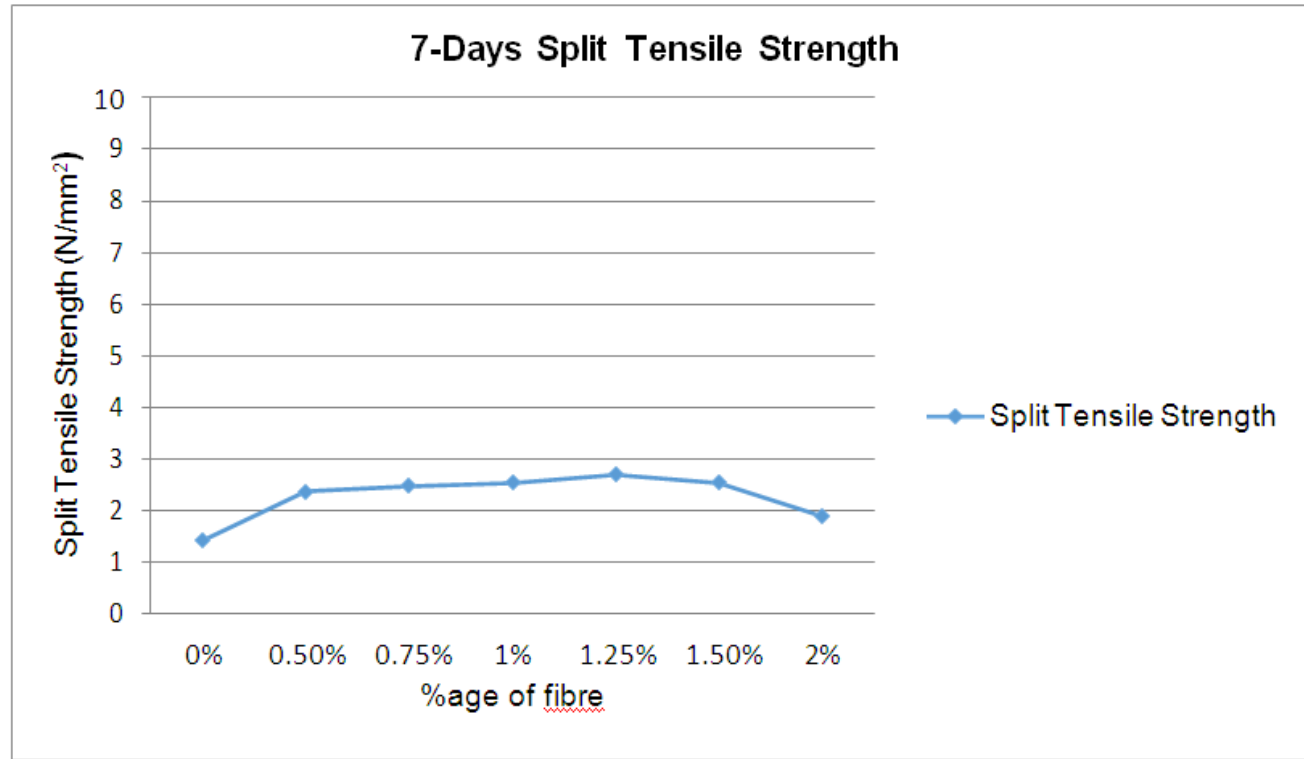

GRAPH 6: 7 DAY SPLIT TENSILE STRENGTH OF CYLINDER SPECIMENS

\section{FIG 11: BEHAVIOUR OF CYLINDER SPECIMENS WITH FIBRES (LEFT) AND WITHOUTN FIBRES (RIGHT) SUBJECTED TO SPLIT TENSILE STRENGTH TEST AFTER 7 DAYS}

28 day split tensile strength

TABLE 23: 28-DAYS SPLIT TENSILE STRENGTH TEST

\begin{tabular}{|c|c|c|c|c|c|}
\hline S.No & $\begin{array}{c}\text { Date of } \\
\text { Casting }\end{array}$ & $\begin{array}{c}\text { Date of } \\
\text { Testing }\end{array}$ & $\begin{array}{c}\text { \%age of } \\
\text { Fibres }\end{array}$ & $\begin{array}{c}\text { Avg. Load in } \\
\text { KN }\end{array}$ & $\begin{array}{c}\text { Avg. Split Tensile } \\
\text { Strength in N/mm² }\end{array}$ \\
\hline 01 & $14-04-15$ & $21-04-15$ & $0 \%$ & 125 & 3.97 \\
\hline 02 & $14-04-15$ & $22-04-15$ & $0.5 \%$ & 130 & 4.13 \\
\hline 03 & $18-04-15$ & $25-04-15$ & $0.75 \%$ & 150 & 4.77 \\
\hline 04 & $22-04-15$ & $29-04-15$ & $1 \%$ & 180 & 5.72 \\
\hline 05 & $08-05-15$ & $15-04-15$ & $1.25 \%$ & 190 & 6.04 \\
\hline 06 & $28-05-15$ & $04-06-15$ & $1.5 \%$ & 175 & 5.57 \\
\hline 07 & $04-06-15$ & $11-06-15$ & $2 \%$ & 150 & 4.77 \\
\hline
\end{tabular}




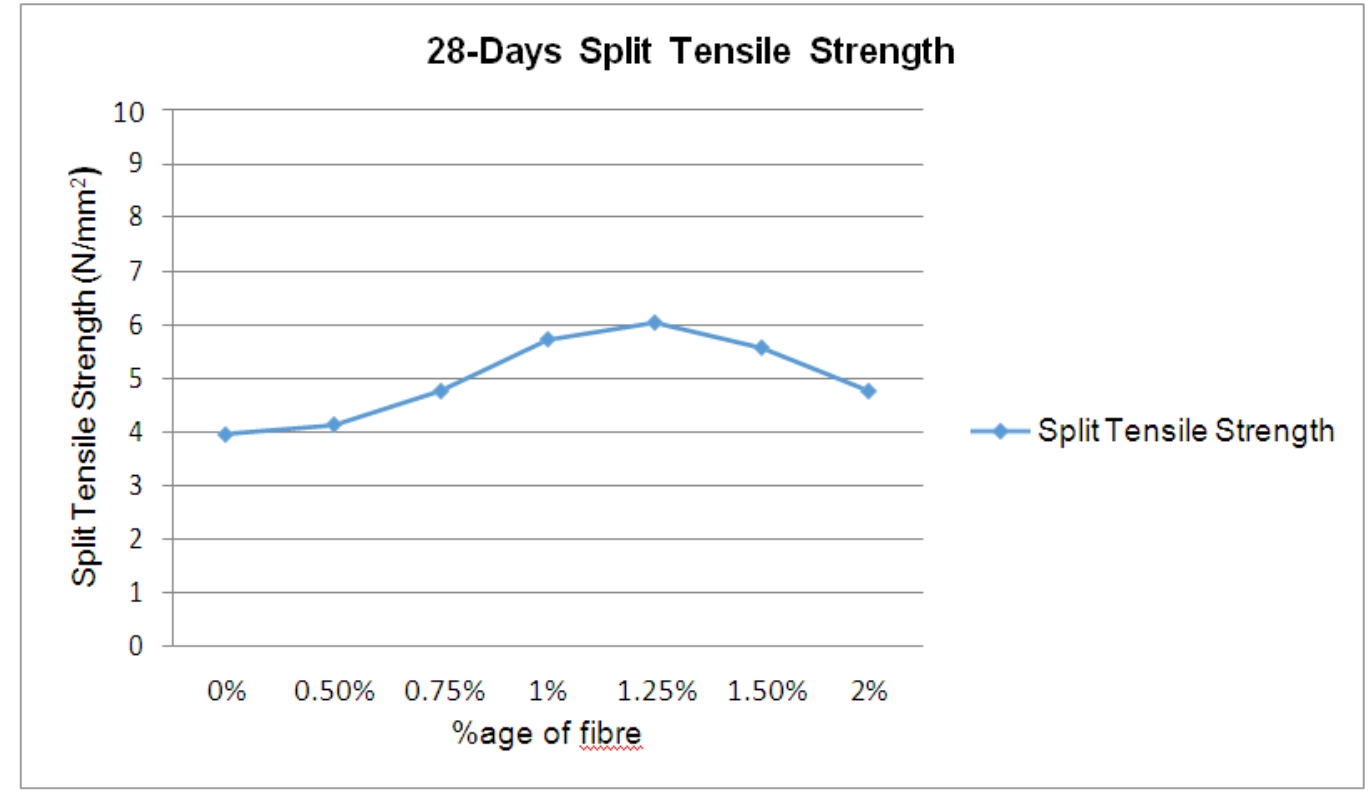

GRAPH 7: 28 DAY SPLIT TENSILE STRENGTH TEST

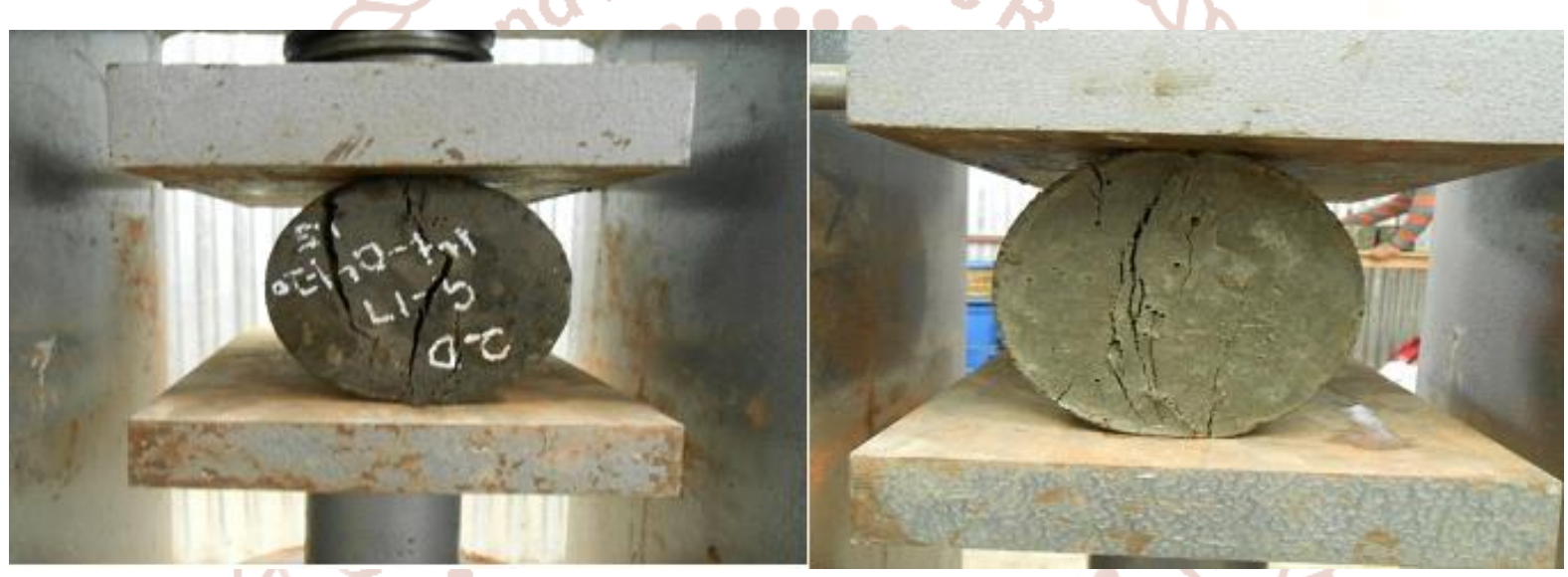

FIG 12: COMPARISON OF DEVELOPMENT OF CRACKS IN ORDINARY CONVRETE (LEFT) AND FRC (RIGHT) UNDER TENSILE FORCES AFTER 28 DAYS

Comparison of Split Tensile Strength at 3, 7 and 28 days

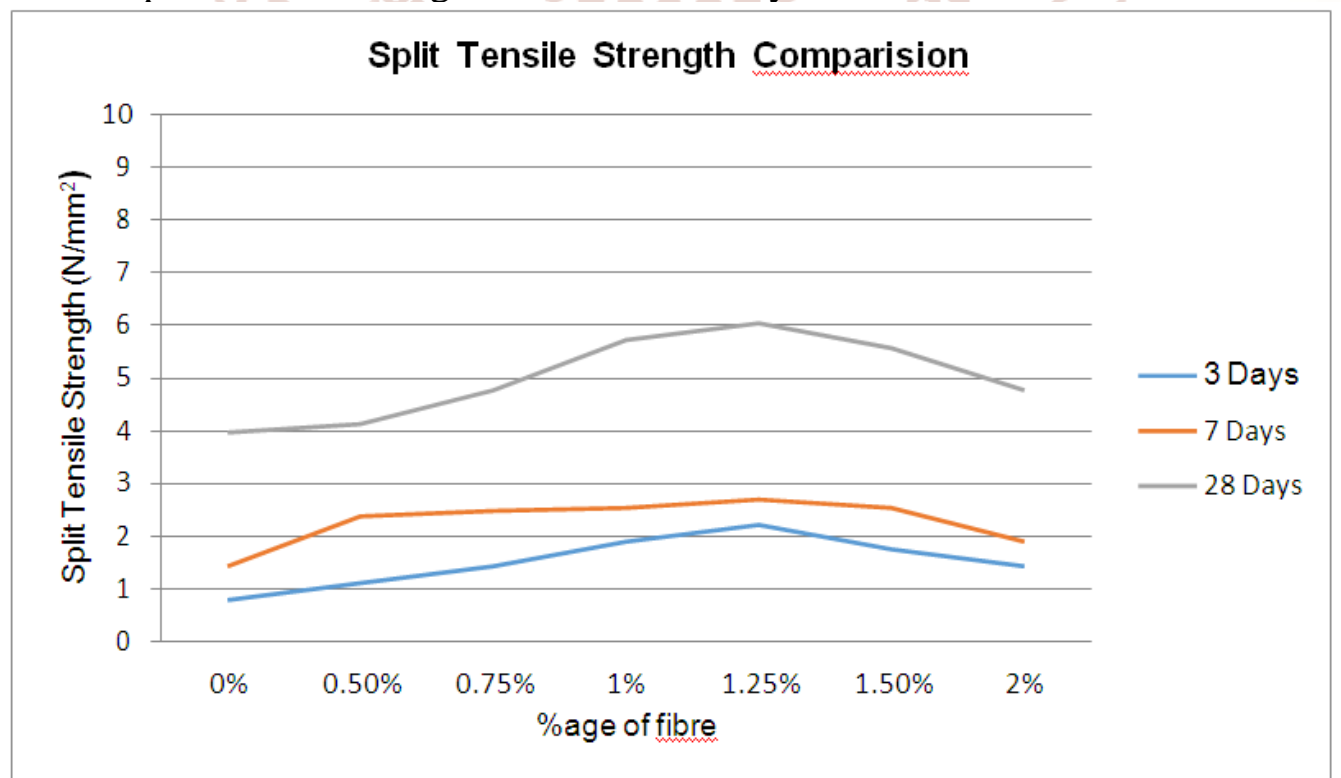

GRAPH 8: COMPARISON OF SPLIT TENSILE STRENGTH OF SFRC AT 3, 7, AND 28 DAYS 
International Journal of Trend in Scientific Research and Development (IJTSRD) ISSN: 2456-6470

5. FLEXURAL STRENGTH

$>$ day flexure test

Table 24: Flexure strength at 3 days

\begin{tabular}{|c|c|c|c|c|c|}
\hline S.No & \%age of fibre & $\begin{array}{c}\text { Trial 1 } \\
\text { LOAD } \\
\text { IN KN }\end{array}$ & $\begin{array}{c}\text { Trail 2 } \\
\text { LOAD IN } \\
\text { KN }\end{array}$ & $\begin{array}{c}\text { Avg. Load } \\
\text { IN KN }\end{array}$ & $\begin{array}{c}\text { Avg. Modulus of } \\
\text { Rupture }\end{array}$ \\
\hline 01 & $0 \%$ & 4 & 4.5 & 4.25 & 2.125 \\
\hline 02 & $0.5 \%$ & 4.75 & 5 & 4.875 & 2.45 \\
\hline 03 & $0.75 \%$ & 6 & 8 & 7 & 3.5 \\
\hline 04 & $1 \%$ & 8 & 9.05 & 8.7 & 4.35 \\
\hline 05 & $1.25 \%$ & 8.4 & 8.4 & 8.4 & 4.2 \\
\hline 06 & $1.5 \%$ & 6 & 6.5 & 6.25 & 3.125 \\
\hline 07 & $2 \%$ & 5 & 4 & 4.5 & 2.25 \\
\hline
\end{tabular}

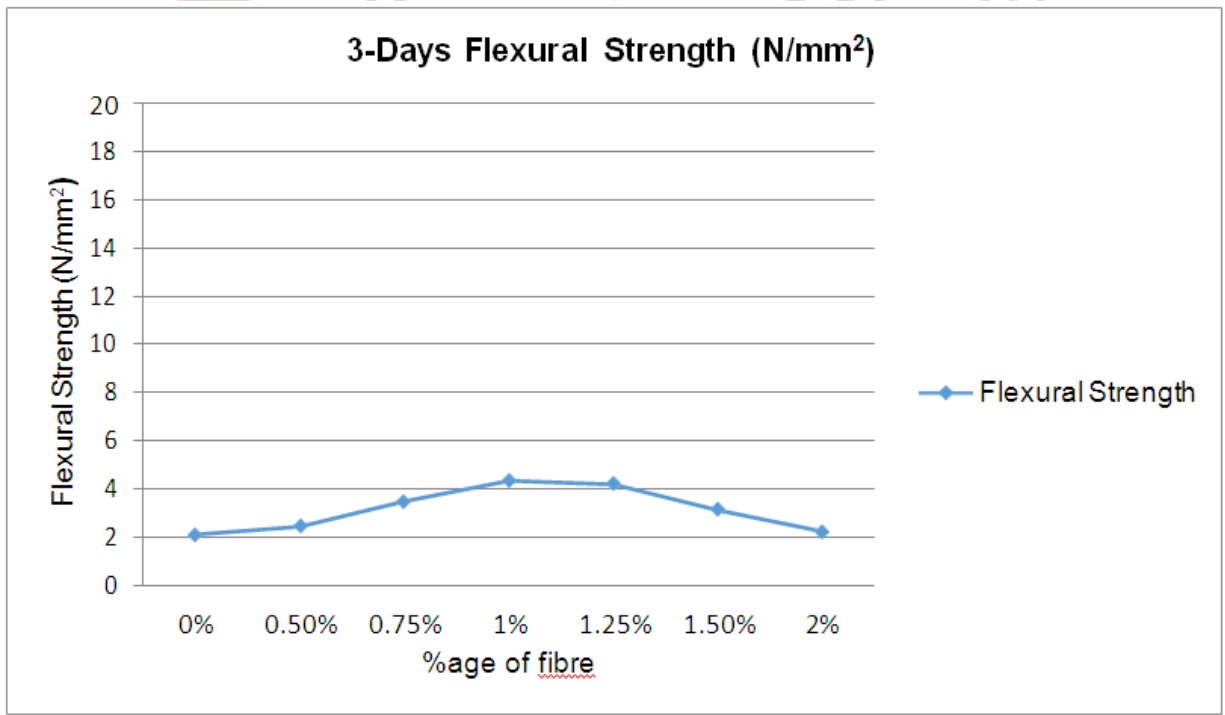

GRAPH 9: Flexure strength at 3 day

- 7 Day flexure test

Table 25: flexure strength values at 7 days

\begin{tabular}{|c|c|c|c|c|c|}
\hline S.No & \%age of fibre & $\begin{array}{c}\text { Trial 1 } \\
\text { LOAD } \\
\text { IN KN }\end{array}$ & $\begin{array}{c}\text { Trail 2 } \\
\text { LOAD IN } \\
\text { KN }\end{array}$ & $\begin{array}{c}\text { Avg. Load } \\
\text { IN KN }\end{array}$ & $\begin{array}{c}\text { Avg. Modulus of } \\
\text { Rupture }\end{array}$ \\
\hline 01 & $0 \%$ & 10 & 11.5 & 10.75 & 5.375 \\
\hline 02 & $0.5 \%$ & 13 & 13.9 & 13.45 & 6.73 \\
\hline 03 & $0.75 \%$ & 14.1 & 14.3 & 14.2 & 7.1 \\
\hline 04 & $1 \%$ & 17 & 17.9 & 17.45 & 8.73 \\
\hline 05 & $1.25 \%$ & 17 & 15 & 16 & 8 \\
\hline 06 & $1.5 \%$ & 13 & 12.5 & 12.75 & 6.37 \\
\hline 07 & $2 \%$ & 10 & 11 & 10.5 & 5.25 \\
\hline
\end{tabular}




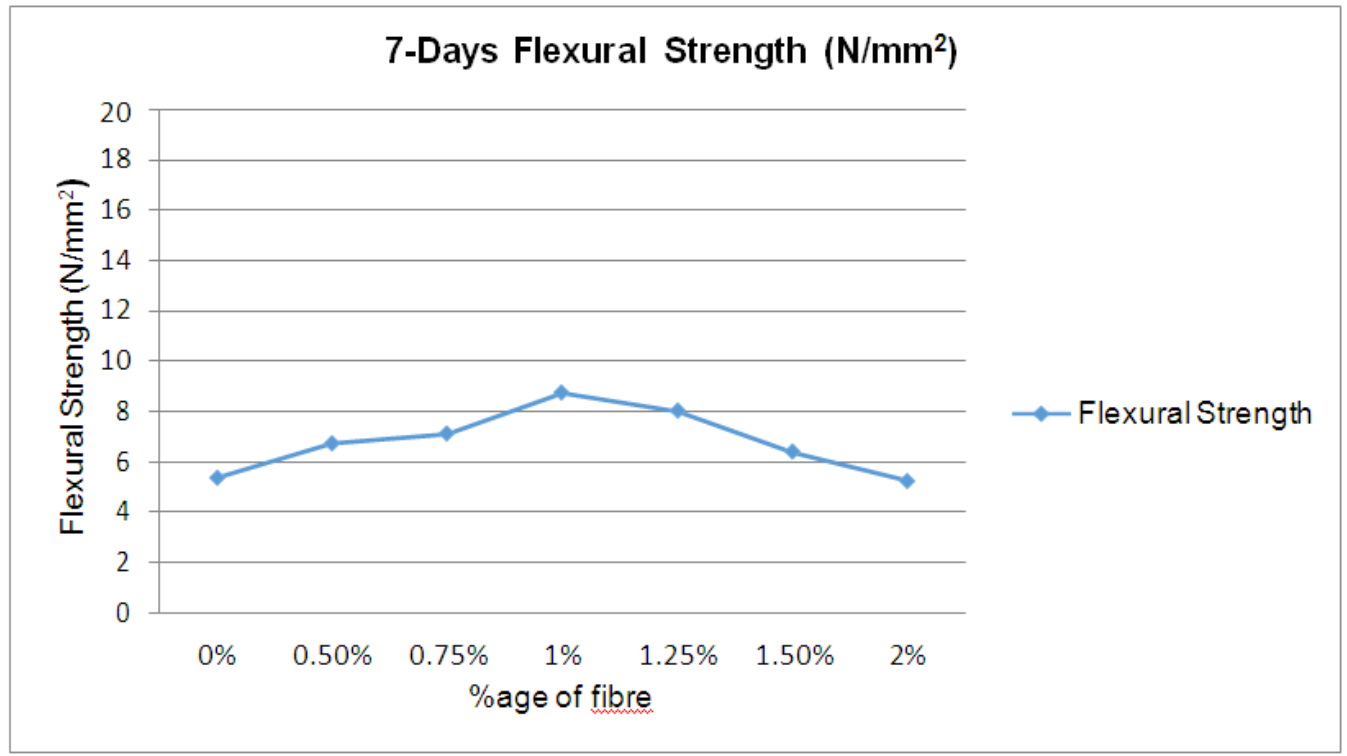

28 day flexural strength

TABLE 26. FLEXURAL TEST VALUES AT 28 DAYS CURING

\begin{tabular}{|c|c|c|c|c|c|}
\hline S.No & \%age of fibre & $\begin{array}{l}\text { Trial } 1 \\
\text { LOAD } \\
\text { IN KN }\end{array}$ & $\begin{array}{c}\text { Trail } 2 \\
\text { LOAD IN } \\
\text { KN }\end{array}$ & $\begin{array}{l}\text { Avg. Load } \\
\text { IN KN }\end{array}$ & $\begin{array}{l}\text { Avg. Modulus of } \\
\text { Rupture }\end{array}$ \\
\hline 01 & $0 \%$ & 22.5 & na 2304 & In 22.75 & 11.37 \\
\hline 02 & $0.5 \%$ & T $28.5 \mathrm{~d}$ & n 29 ien & Lifili 28.75 & 14.37 \\
\hline 03 & $0.75 \%$ & R32se & rec 34 and & 33 & 16.50 \\
\hline 04 & $1 \%$ & $35 \mathrm{Ve}$ & $35.5 \mathrm{en}$ & 35.25 & 17.62 \\
\hline 05 & $1.25 \%$ & 37.5 & 38.2 & 37.85 & 16.25 \\
\hline 06 & $1.5 \%$ & 28.5 & 27.2 & 27.85 & 14.5 \\
\hline 07 & $2 \%$ & 25.5 & 25 & 25.25 & 12 \\
\hline
\end{tabular}

GRAPH 9: FLEXURAL STRENGTH OF SFRC AFTER 28 DAYS

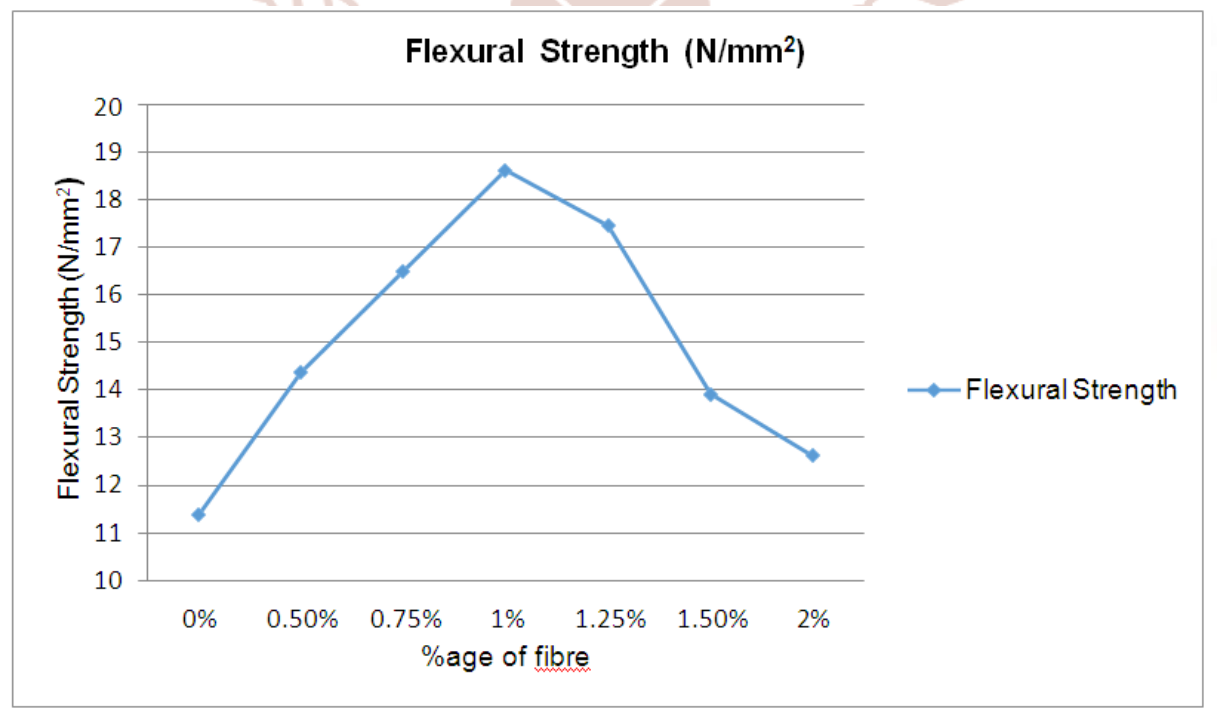




\section{INTERPRETATION OF RESULTS}

\section{Compressive Strength and Split Tensile Strength:}

The variation in the compressive stress and split tensile stress with respect to changes in the fibre content can be observed. From the results obtained, it is clear that the compressive and split tensile strength of concrete is maximum when the fibre content is $1.25 \%$ of the concrete.

Table 27: Variation in compressive strength

\begin{tabular}{|c|c|c|c|c|}
\hline \multirow{2}{*}{$\begin{array}{c}\text { PLAIN } \\
\text { CONCRETE }\end{array}$} & \multirow{2}{*}{$\begin{array}{c}\text { FIBRE REIBFORCED } \\
\text { CONCRETE }\end{array}$} & \multicolumn{3}{|c|}{ PERCENTAGE INCREASE } \\
\cline { 2 - 5 } & & $3 \mathrm{~d}$ & $7 \mathrm{~d}$ & $28 \mathrm{~d}$ \\
\hline \multirow{5}{*}{$\mathbf{4} \%$} & $0.5 \%$ & 4.0 & 22.1 & 11.7 \\
\cline { 2 - 5 } & $0.75 \%$ & 6.7 & 23.1 & 16.7 \\
\cline { 2 - 5 } & $1.0 \%$ & 12 & 27.2 & 20 \\
\cline { 2 - 5 } & $1.25 \%$ & 13 & 29.3 & 22.5 \\
\cline { 2 - 5 } & $1.5 \%$ & 4 & 21.1 & 16.7 \\
\cline { 2 - 5 } & $2.0 \%$ & -14 & 2.6 & 10 \\
\hline
\end{tabular}

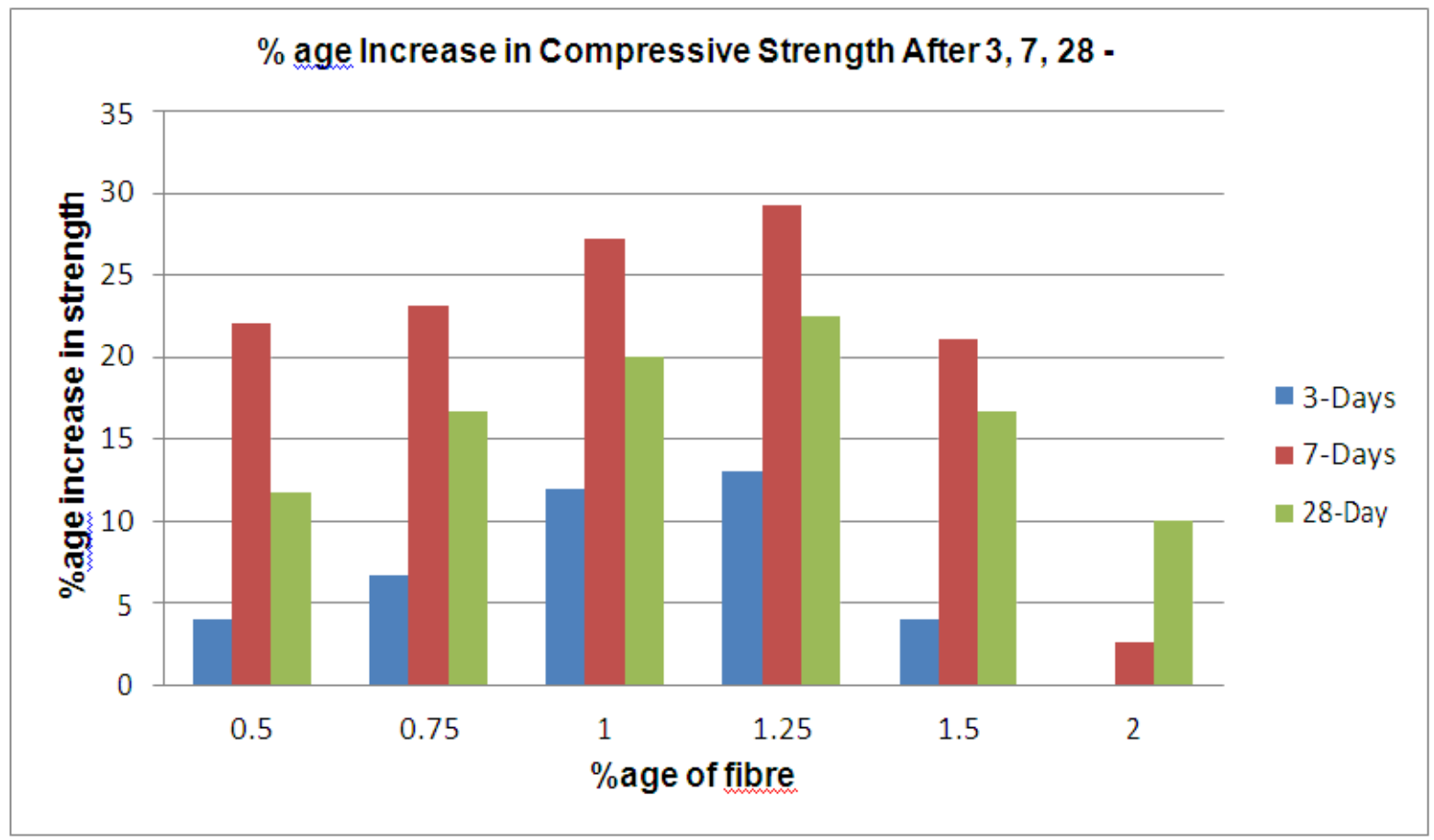

Table 28: Variation in tensile strength values

\begin{tabular}{|c|c|c|c|c|}
\hline \multirow{2}{*}{ PLAIN CONCRETE } & \multirow{2}{*}{$\begin{array}{c}\text { FIBRE } \\
\text { REIBFORCED } \\
\text { CONCRETE }\end{array}$} & \multicolumn{3}{|c|}{ PERCENTAGE INCREASE } \\
\cline { 2 - 5 } & $0.5 \%$ & $3 \mathrm{~d}$ & $7 \mathrm{~d}$ & $28 \mathrm{~d}$ \\
\hline \multirow{3}{*}{$0 \%$} & $0.75 \%$ & 40.5 & 66.4 & 4 \\
\cline { 2 - 5 } & $1.0 \%$ & 81 & 73.4 & 20.2 \\
\cline { 2 - 5 } & $1.25 \%$ & 140.5 & 77.6 & 44.1 \\
\cline { 2 - 5 } & $1.5 \%$ & 121.5 & 88.8 & 52.1 \\
\cline { 2 - 5 } & $2.0 \%$ & 81 & 32.9 & 20.2 \\
\hline
\end{tabular}




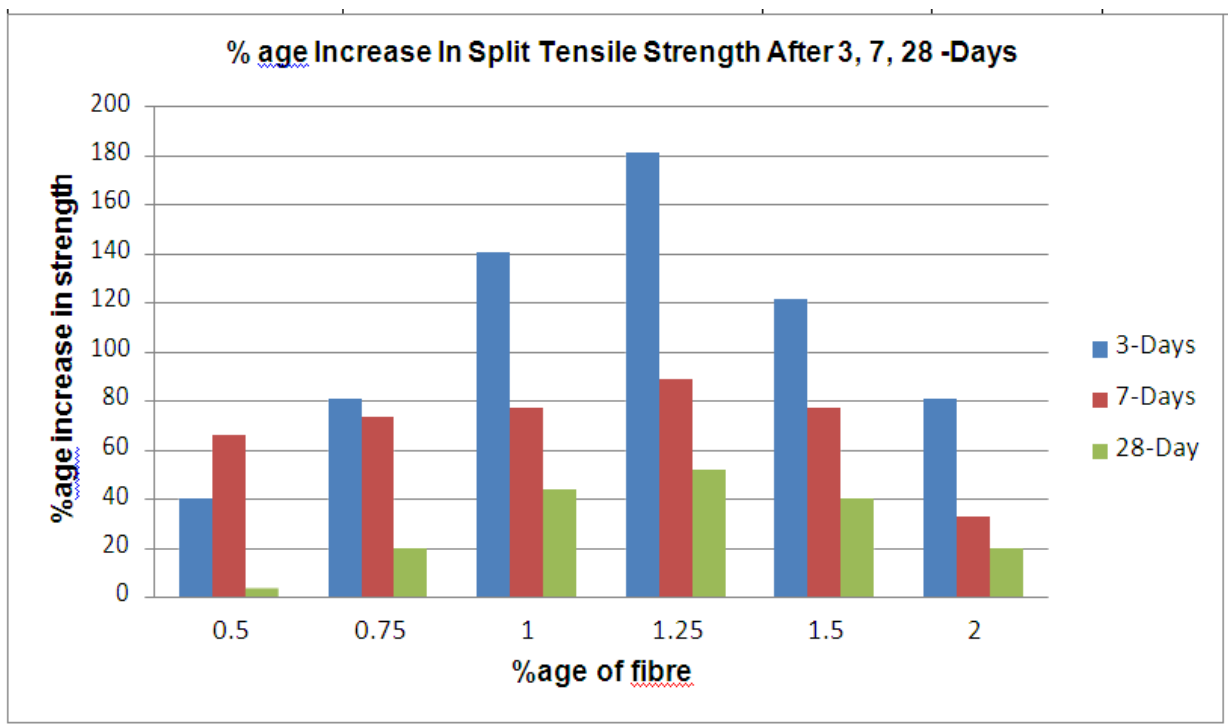

Flexural Strength (Modulus of Rupture):

From the results obtained, it is inferred that the most significant increase in the Modulus of Rupture is obtained on addition of 1 percent of fibres. So, comparing the values of increase in strength:

Table 29: Variation in flexural strength

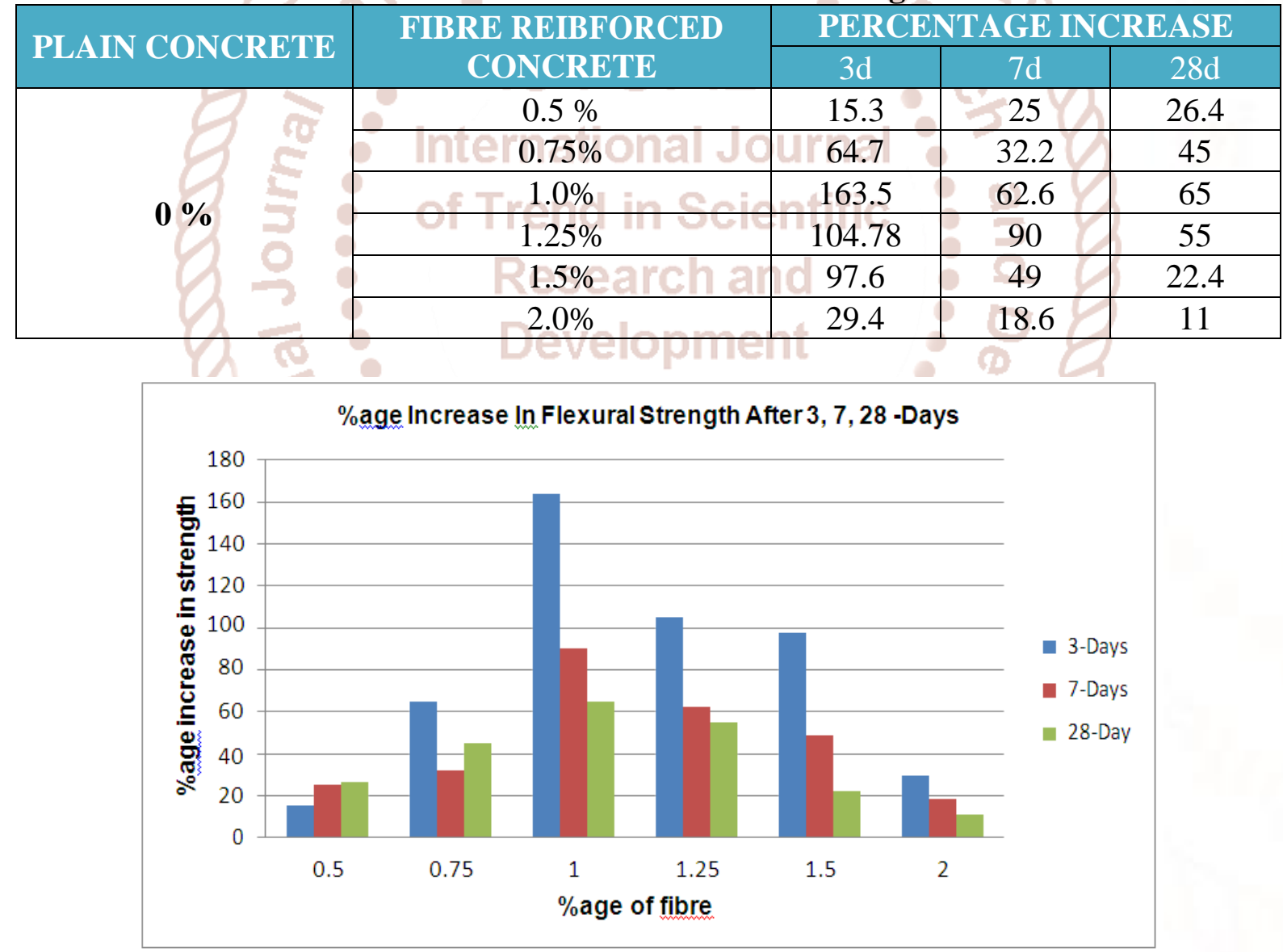

\section{CONCLUSION AND RECOMMENDATIONS}

The increasing interest in the use of fibre reinforcement has created a need for established design and analysis methods. Fibre reinforcement is mainly used in applications such as industrial floors and sprayed concrete, although other application areas exist. Apart from increase load carrying capacity, one of the main benefits of adding fibers to concrete is the potential reduction in crack width which depends on the amount of fibers added and positively affects the durability of the finished structure. High early strength concrete, when reinforced with fibers, can be used for several highway related applications. They include 
repair-type applications for which early strength properties are needed such as for potholes, bridge decks, overlays, pavement joints, and runways; and applications in new structures particularly bridge decks, pavements, median barriers, taxiways, and runways. Tunnel lining, slope stabilization, dams, hydraulic structures, and blast resistant structures also utilize high early strength fibre reinforced concrete for various purposes. After Careful and elaborate study of the effect of steel fibre reinforcement on Early Strength concrete, it can be concluded that

1. The compressive strength of concrete for the cubes with steel fibers $0.25 \%, 0.50 \%$, $0.75 \%, 1 \%, 1.25 \%, 1.5 \%$, and $2 \%$ is more than that of cubes without steel fibers. This may be due to the fact that the steel fibers will effectively hold the micro cracks in concrete mass. The percentage increase in the compressive strength for the cubes with steel fibers $0.25 \%, 0.50 \%$, $0.75 \%, 1 \%, 1.25 \%, 1.5 \%$ and $2 \%$ compared to the cubes without steel fibers are $11.70 \%$, $16.70 \%, 20.0 \%, 22.50 \%, 16.7 \% \& 10 \%$ respectively. However maximum percentage increase in compressive strength can be obtained for the cubes with steel fibers $1.25 \%$ by volume of concrete $(+22.50 \%)$. Thus it is recommended to use steel fibers $1.25 \%$ by volume of concrete to get the maximum benefit in improving compressive strength.

2. The addition of steel fibers at $1 \%$ by volume causes a considerable improvement in early as well as long term split tensile strength of concrete. The maximum improvement in 28-days strength was observed to be $52.1 \%$. Hence $1.25 \%$ fiber content is optimum fiber content for 70 aspect ratio fiber from split tensile strength point of view. Thus it is recommended to use steel fibers $1.25 \%$ by volume of concrete to get the maximum benefit in improving split tensile strength.

3. The percentage increase in the flexural strength for the beams with steel fibers $0.25 \%, 0.50 \%$, $0.75 \%, 1 \%, 1.25 \%, 1.5 \%$ and $2 \%$ compared to the beams without steel fibers are $+26.4 \%$, $+45 \%,+65 \%,+55 \% \quad+22.4 \%, \quad$ and $+11 \%$ respectively. It can be seen from the observations that the maximum percentage increase in flexural strength can be obtained for the beams with steel fibers $1.0 \%$ by volume of concrete $(+65 \%)$. Thus it is recommended to use steel fibers $1.0 \%$ by volume of concrete to get the maximum benefit in improving flexural strength.
4. The workability of fresh concrete was found to decrease with an increase in the fiber content. There was also a decrease in the workability with the increase in the aspect ratio.

In nutshell it can be concluded that the use of steel fibers is an effective method to improve the flexural, Split Tensile \& compressive strength of concrete. To get the maximum benefit it is recommended to use steel fibers $1.0 \%$ by volume of concrete. More percentage of steel fibers will have the workability problem $\&$ also air cavities are left in the system.

\section{REFERENCES}

1. "Fibre reinforced concrete Under Cyclic And Dynamic Loading" D.E.Ottor And A.E.Namaan 1988'

2. 'Bond Behaviour Of Normal And High Strength Fibre reinforced concrete" ACI Material Journal 86 1985, Ezeldin And Balaguru [1992]

3. "Experimental Investigation Cement And Concrete Research "V. S Gopalaratanam, S.P. Shah

4. "Steel Fiber Reinforced Concrete" J. Endgington, D.J. Hannant \& R.I.T. Williams, Current Paper CP 69/74 Building Research Establishment Garston Watford 1974.

5. "Experimental Investigation Of Fibre Reinforced Concrete With Partial Replacement Of Coarse Aggregate By Steel Slag' N. Manoj, Mrs. N. Nandhini, International Journal Of Innovative Research In Science, Engineering And Technology Volume 3, Special Issue 2, April 2014

6. "Fiber Reinforced Concrete- Behaviour Properties And Application" Dr. M. C. Nataraja

7. Concrete technology by M. S. Shetty

8. IS 456:2000,Code of practice for concrete design

9. IS 10262:2009, Guidelines for concrete mix proportions

10. IS 4031:1988 part iv , Guidelines for method of test of aggregate

11. IS 4031:1988 part v, Guidelines for method of test of aggregate

12. IS 12269:1988, Specifications for 53 grade cement

13. IS 383:1970, Specifications for coarse and fine aggregates

14. IS 4926:2003, Code of practice for ready mix con 